\title{
Discovery of a highly active anticancer analogue of cardamonin that acts as an inducer of caspase-dependent apoptosis and modulator of the mTOR pathway
}

Mohammed Khaled bin Break ${ }^{\mathrm{a}}$, Md Shahadat Hossan ${ }^{\mathrm{b}}$, Yivonn Khoo ${ }^{\mathrm{a}}$, Sek Chuen Chow $^{\mathrm{c}}$, Christophe Wiart ${ }^{\mathrm{a}}$, Tracey D. Bradshaw ${ }^{\mathrm{b}}$, Hilary Collins ${ }^{\mathrm{b}}$ and Teng-Jin Khoo ${ }^{\mathrm{a},}$,

${ }^{a}$ Centre for Natural and Medicinal Product Research, School of Pharmacy, University of Nottingham Malaysia Campus, 43500 Semenyih, Malaysia

${ }^{\mathrm{b}}$ School of Pharmacy, Centre for Biomolecular Science, University of Nottingham, University Park, Nottingham, $U K$

'School of Science, Monash University Sunway Campus, Jalan Lagoon Selatan, Bandar Sunway, 46150, Selangor Darul Ehsan, Malaysia

* Corresponding author.

Tel.: +60389248213

fax: +60389248018

E-mail: TengJin.Khoo@ nottingham.edu.my 


\begin{abstract}
Nineteen analogues of cardamonin were semi-synthesized and tested against A549 and HK1 cell lines. The analogues were fully characterized via IR and NMR analyses, while compound 19 (a $\mathrm{Cu}$ (II) complex of cardamonin) was further characterized via HRMS, ELEMENTAL ANALYSIS, TGA and UV-VIS spectroscopy. Results of the MTS cell viability assay showed that several derivatives possessed cytotoxic activities that were several-fold more potent than cardamonin. Compound 19 was the most potent analogue possessing $\mathrm{IC}_{50}$ values of $13.2 \mu \mathrm{M}$ and $0.7 \mu \mathrm{M}$ against A549 and HK1 cells, corresponding to a 5- and 32-fold increase in activity, respectively. Furthermore, the active analogues, especially 19, have generally demonstrated lower toxicity towards normal MRC5 cells. SAR analysis showed the importance of the ketone and alkene groups for bioactivity, while substituting cardamonin's phenolic groups with more polar moieties resulted in activity enhancement. As part of the SAR study and further exploration of chemical space, the effect of metal coordination on cytotoxicity was also investigated, but it was only possible to successfully obtain the $\mathrm{Cu}$ (II) complex of cardamonin (19), and results showed that the metal ion enhanced activity. 19 was also able to significantly inhibit the migration of A549 and HK1 cells. Further studies have shown that the most active analogue, 19, induced DNA damage resulting in G2/M-phase cell-cycle arrest in both cell lines. These events further led to the induction of apoptosis by 19 via caspase-3/7 and caspase- 9 activation, PARP cleavage and downregulation of Mcl-1 expression. Finally, 19 inhibited the expression levels of $\mathrm{p}-\mathrm{mTOR}$ and $\mathrm{p}-4 \mathrm{EBP} 1$. These data indicated that $\mathbf{1 9}$ exerted its anticancer activity, at least in part, via inhibition of the mTOR signalling pathway.
\end{abstract}

Keywords: Cardamonin; Semi-synthesis; Cytotoxicity; Caspase; Cell-cycle arrest; mTOR 


\section{Introduction}

Cancer is considered to be a major health concern and a leading cause of death worldwide with $\sim 14$ million new cases and 8.2 million deaths in 2012, while it is expected that the number of new cases would increase by $70 \%$ over the next two decades. Lung cancer is responsible for most cancer-related deaths globally with 1.59 million deaths reported in 2012. Another type of cancer that is mostly prevalent in Asia is nasopharyngeal carcinoma (NPC) and this cancer is known to have a low survival rate making it a serious health problem. There is currently no cure for any of these two types of cancer and the drugs approved for treatment are usually accompanied by toxic side effects, therefore there is a need for further research aimed at developing more effective anticancer compounds [1-2].

Natural products are considered to be a rich source of bioactive molecules and have been studied extensively for the purpose of finding potent anticancer compounds. Chalcones, also known as 1,3-diaryl-2-propen-1-ones, are a group of naturally occurring compounds that are usually responsible for the yellow pigmentation in plants and belong to the flavonoid family. Chalcones are characterized by the presence of an $\alpha, \beta$-unsaturated ketone with two aromatic rings. This group of compounds has been reported to possess a wide range of bioactivities including antitumour, antioxidant, antimitotic and antitumour activities [3].

Cardamonin is a chalcone that has been extracted from several plants including Alpinia rafflesiana and was proven to possess cytotoxic properties against a wide variety of cancer cell lines such as A549, U266, HuCCA-1 and MOLT-3 [4]. Moreover, cardamonin's mode of action has been extensively studied, where it was found that it exerted its anticancer activity via modulation of several pathways such as $\mathrm{Wnt} / \beta$-catenin and NF- $\kappa \mathrm{B}$ signalling pathways [5$6]$. However, there have been no studies performed on semi-synthetic analogues of cardamonin with anticancer properties, nor have there been any detailed investigations on the structureactivity relationship of cardamonin specifically.

Therefore, the main aim of the present study is to find active analogues of cardamonin via semisynthesis and to test their anticancer potential against A549 (lung) and HK1 (NPC) cancer cell lines. The chemical transformations considered for producing the analogues ranged from condensation and cyclization reactions to metal complexation reactions. This wide range of chemical transformations was considered in order to produce analogues with more chemical diversity that might result in a variety of novel bioactive analogues. Herein, we describe the identification of $\mathrm{Cu}$ (II) complex of cardamonin (19) as a highly active anticancer compound, in addition to the further investigation of its mode of action. 


\section{Results and discussion}

\subsection{Chemistry}

\subsubsection{Synthesis}

The analogues of cardamonin were synthesized according to Scheme 1. Initially, the phenolic groups of cardamonin were targeted for modification by alkylation and acylation reactions. Alkylation proceeded by refluxing cardamonin with an alkyl halide and $\mathrm{K}_{2} \mathrm{CO}_{3}$ in acetone, while acylation generally involved refluxing cardamonin with an acyl halide/acetic anhydride.

Importance of the alkene group for bioactivity was investigated by reducing it, and this was performed by the synthesis of dihydrochalcone 7 and flavanone $\mathbf{1 7}$. The reduction of cardamonin via $\mathrm{NaBH}_{4}$ in order to produce 7 resulted in a mixture of products that proved difficult to separate. Therefore, selective reduction of cardamonin's alkene group via the $\mathrm{NiCl}_{2} / \mathrm{NaBH}_{4}$ system at $0{ }^{\circ} \mathrm{C}$ was considered, and that produced 7 but in low yield. Flavanone 17 was produced by refluxing cardamonin with concentrated $\mathrm{HCl}$ in methanol for $72 \mathrm{~h}$.

Cardamonin's ketone group was modified by Schiff base formation and cyclization reactions. Schiff bases were formed by reacting cardamonin with primary amine hydrochlorides and SBDTC. The amine, SBDTC, was synthesized as previously reported [7], and was considered due to its known bioactivity. Cyclic rings were produced by reacting cardamonin with $\mathrm{NH}_{2} \mathrm{NH}_{2} \cdot \mathrm{H}_{2} \mathrm{O}$ and $\mathrm{NH}_{2} \mathrm{OH}$ to yield pyrazoline 11 and isoxazoline 12, respectively. Furthermore, pyrimidine rings were also produced by reacting cardamonin with urea and thiourea in the presence of $\mathrm{NaOH}$ to synthesize 13 and 14, respectively.

Synthesis of flavanone $\mathbf{1 7}$ encouraged us to synthesize the flavone analogue of cardamonin by reacting the chalcone with $\mathrm{I}_{2}$-DMSO, in order to compare and further investigate the importance of the alkene group. Surprisingly, no flavone was obtained, rather nuclear halogenation occurred at ring A resulting in 15. The case was similar with 16. Flavone synthesis was attempted again using $\mathrm{FeCl}_{3}$ but was still unsuccessful [8]. Finally, a previously reported method that used oxalic acid for flavone synthesis was considered but the attempt has also failed [9], and interestingly another study also reported the failure of this method [10]. It seems that substituents at ring A affected the side-chain halogenation of cardamonin, as otherwise the intended derivatives were readily obtained in previous studies [11-12]. However, the unexpected iodination and bromination of ring A encouraged us to perform chlorination and that was attempted using $N$-chlorosuccininimide but the reaction failed. Synthesis of flavonol 18 proceeded smoothly and involved reacting caradmonin with $30 \% \mathrm{H}_{2} \mathrm{O}_{2}$ and $\mathrm{NaOH}$.

Production of the $\mathrm{Cu}$ (II) complex of cardamonin (19) required the addition of a base as no reaction occurred without it, this suggested that deprotonation of 2'-OH was crucial for complexation. Imidazole was initially used as a mild base and this produced $\mathbf{1 9}$ in low yields, so $\mathrm{NaOH}$ was used instead resulting in a much higher yield. It is crucial to note that coordinating cardamonin to other metal ions, such as $\mathrm{Fe}^{2+}, \mathrm{Co}^{2+}$ and $\mathrm{Ni}^{2+}$ via reacting cardamonin with $\mathrm{FeCl}_{2}, \mathrm{CoCl}_{2}$ and $\mathrm{NiCl}_{2}$ in ethanol, was not successful. 


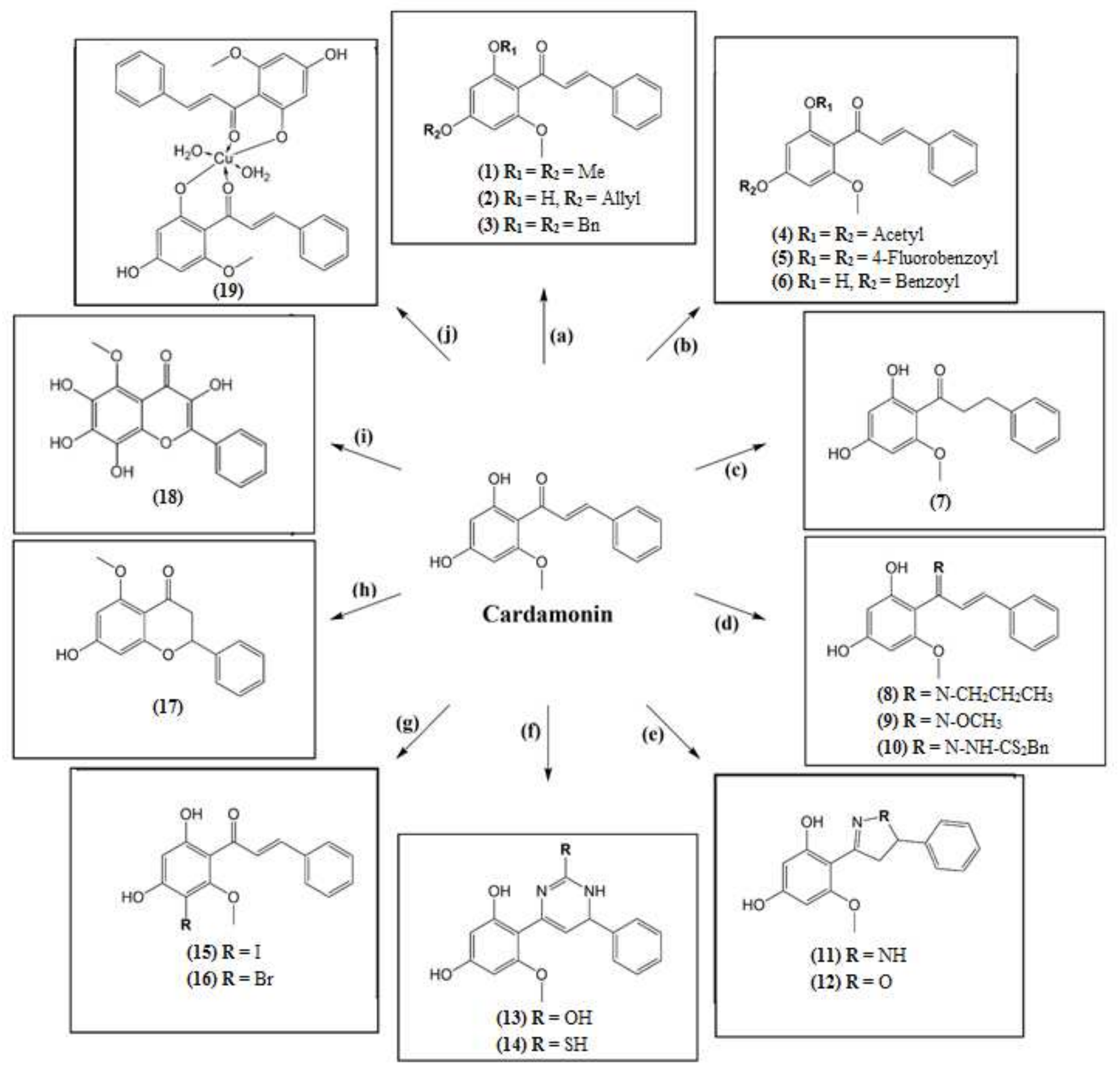


Scheme 1. Semi-synthesis of cardamonin analogues. Reagents and conditions: (a) $\mathrm{K}_{2} \mathrm{CO}_{3}$, alkyl halide, acetone, reflux; (b) pyridine, DMAP, acyl halide/acetic anhydride, DCM, reflux; (c) $\mathrm{NiCl}_{2}, \mathrm{NaBH}_{4}$, methanol, ice-bath; (d) $\mathrm{HCl}$, primary amine, methanol, reflux; (e) $\mathrm{NH}_{2} \mathrm{NH}_{2} \cdot \mathrm{H}_{2} \mathrm{O}$ / $\mathrm{NH}_{2} \mathrm{OH}$, methanol, reflux; (f) urea/thiourea, $\mathrm{NaOH}, 80 \%$ ethanol, reflux; (g) $\mathrm{I}_{2}$, DMSO, reflux for (15)/ $\mathrm{Br}_{2}, \mathrm{CHCl}_{3}$, reflux for (16); (h) $\mathrm{HCl}$, methanol, reflux; (i) $30 \% \mathrm{H}_{2} \mathrm{O}_{2}, \mathrm{NaOH}$, methanol, rt; (j) $\mathrm{Cu}(\mathrm{OAc})_{2}, \mathrm{NaOH}$, methanol, reflux. 


\subsubsection{Structure and characterization}

\section{$\underline{\text { Semi-synthetic analogues (1-18) }}$}

The semi-synthetic analogues showed similar analytical spectra to cardamonin but with slight variations. IR and NMR analyses were used to deduce the substitution pattern for alkylated/acylated analogues. Apart from the substituents' characteristic spectral peaks, the 2'$\mathrm{OH}$ peak aided in identifying the substitution pattern, whereby the disappearance of a peak at around $3170 \mathrm{~cm}^{-1}$ and $14 \mathrm{ppm}$ indicated that 2'-OH substitution took place. The structure of analogue 7 structure was primarily deduced from its NMR spectrum that showed the appearance of a pair of triplets at $\sim 3 \mathrm{ppm}$, proving reduction of the alkene double bond. The IR spectra for 11 and 12 showed peaks for $(C=N)$ at $1618 \mathrm{~cm}^{-1}$ and $1610 \mathrm{~cm}^{-1}$ characteristic to pyrazoline/isoxazoline rings, respectively. The NMR spectra of both compounds showed the presence of three doublet of doublets at around 4-6 ppm corresponding to protons of the pyrazoline/isoxazoline rings.

IR and NMR spectra were also used to identify the exact structures of 13 and 14 as these compounds are known to exhibit tautomerism. IR spectra showed peaks at $1661 \mathrm{~cm}^{-1}$ which were attributed to $(\mathrm{C}=\mathrm{N})$ of the pyrimidine ring, while the peaks at around $3222 \mathrm{~cm}^{-1}$ and 1601 $\mathrm{cm}^{-1}$ have been assigned to $(\mathrm{N}-\mathrm{H})$ stretch and bend, respectively. NMR spectra showed a pair of doublets at $\sim 5.5 \mathrm{ppm}$ which suggested that the methine proton of the pyrimidine ring is coupled with an adjacent proton (Cㅍ-NH). Combining all these spectral data enabled structural and tautomeric state determination of the compounds.

Structures of $\mathbf{1 7}$ and $\mathbf{1 8}$ were mainly deduced from their NMR spectra. The absence of peaks corresponding to 2'-OH, H-7 and H-8 proved that intracyclization occurred, while appearance of characteristic peaks for each analogue further confirmed their structures. The NMR spectrum of $\mathbf{1 8}$ showed the absence of a pair of doublets corresponding to H-3' and H-5' which meant that hydroxylation at these positions of ring A had taken place. This was further supported by the singlet peak at $7.65 \mathrm{ppm}$ which integrated to 2 protons corresponding to 3'- $\mathrm{OH}$ and 5' $-\mathrm{OH}$. Characterization of the Schiff bases and halogenated analogues was straightforward and nothing special was noted. 


\section{Metal complex 19}

It was intended to elucidate the structure of $\mathbf{1 9}$ via X-ray crystallography, however, that was not possible. This was due to the inability to grow crystals of the metal complex despite attempts to grow them using a variety of solvents. Therefore, the metal complex was analysed via HRMS, Elemental Analysis, TGA, UV-Vis, IR and NMR spectral analysis.

HRMS analysis showed a clear peak in the spectrum of 19 at 624.0783 (Figure 1) confirming the formation of $\mathbf{1 9}$ in a ligand to metal ratio of 2:1. Elemental analysis data further confirmed the formation of 19 in a ligand to metal stoichiometric ratio of 2:1 and showed that 19 would contain water molecules, so a thermogravimetric analysis (TGA) was conducted to investigate their nature. The TGA curve showed the presence of 2 moles of lattice water and 2 moles of coordinated water. Therefore, it was concluded that the general formula for $\mathbf{1 9}$ would be $\left[\mathrm{Cu}\left(\mathrm{C}_{16} \mathrm{H}_{13} \mathrm{O}_{4}\right)_{2}\left(\mathrm{H}_{2} \mathrm{O}\right)_{2}\right] \cdot 2 \mathrm{H}_{2} \mathrm{O}$.

The UV-Vis spectrum for $\mathbf{1 9}$ showed bands that were attributed to transitions involving the molecular orbitals of $(\mathrm{C}=\mathrm{O})$ and benzene rings. The formation of $\mathbf{1 9}$ was mostly proven by the bands at $506 \mathrm{~nm}$ and $600 \mathrm{~nm}$. The band observed at $506 \mathrm{~nm}$ has been assigned to ligand-tometal charge transfer (LMCT), while the broad band at $600 \mathrm{~nm}$ was attributed to d-d transition. This low-intensity d-d transition broad band at $600 \mathrm{~nm}$ is most likely resulting from ${ }^{2} E_{g} \rightarrow{ }^{2} T_{2 g}$ transition while the broadness of the band is due to dynamic Jahn-Teller distortions. Based on these data, it can be concluded that $\mathbf{1 9}$ possesses a distorted octahedral geometry [13]. Table $\mathbf{1}$ summarizes the HRMS, elemental analysis, TGA and UV-Vis data. 
Table 1. HRMS, Elemental analysis, TGA and UV-Vis data for compound 19

\begin{tabular}{|c|c|}
\hline Compound Formula & {$\left[\mathrm{Cu}\left(\mathrm{C}_{16} \mathrm{H}_{13} \mathrm{O}_{4}\right)_{2}\left(\mathrm{H}_{2} \mathrm{O}\right)_{2}\right] \cdot 2 \mathrm{H}_{2} \mathrm{O}$} \\
\hline HRMS & 624.0783 (Calculated for $\mathrm{C}_{32} \mathrm{H}_{26} \mathrm{CuNaO}_{8}\left[\mathrm{M}^{+}+\mathrm{Na}\right]:$ 624.0827) \\
\hline Elemental Analysis & $\begin{array}{l}\text { \% C: } 57.02 \text { (Calculated: 57.01); } \\
\text { \% H: } 5.08 \text { (Calculated: 4.47) }\end{array}$ \\
\hline $\begin{array}{l}\text { Thermogravimetric } \\
\text { Analysis (TGA) }\end{array}$ & $\begin{array}{l}\text { TWO STEP PROCESS: } \\
\text { 1) } \mathbf{3 0 - 2 0 0}{ }^{\circ} \mathrm{C} \text { ( } 4.1 \% \text { weight loss; } 2 \text { moles of lattice water) } \\
\text { 2) } \mathbf{2 0 6 - 2 6 2}{ }^{\circ} \mathrm{C} \text { ( } 5.6 \% \text { weight loss; } 2 \text { moles of coordinated water) }\end{array}$ \\
\hline UV-Vis $(\lambda \max , \mathbf{n m})$ & $\begin{array}{l}\text { - } 291,352 \text { and } 432\left(\mathbf{n} \rightarrow \pi^{*} \text { and } \boldsymbol{\pi} \rightarrow \boldsymbol{\pi}^{*} \text { transitions) }\right. \\
\text { - } 506 \text { (Ligand-to-metal charge transfer (LMCT)) } \\
\text { - } 600 \text { (d-d transitions; }{ }^{2} \mathbf{E}_{\mathbf{g}} \rightarrow{ }^{2} \mathbf{T}_{\mathbf{2 g}} \text {; indicates octahedral geometry) }\end{array}$ \\
\hline
\end{tabular}




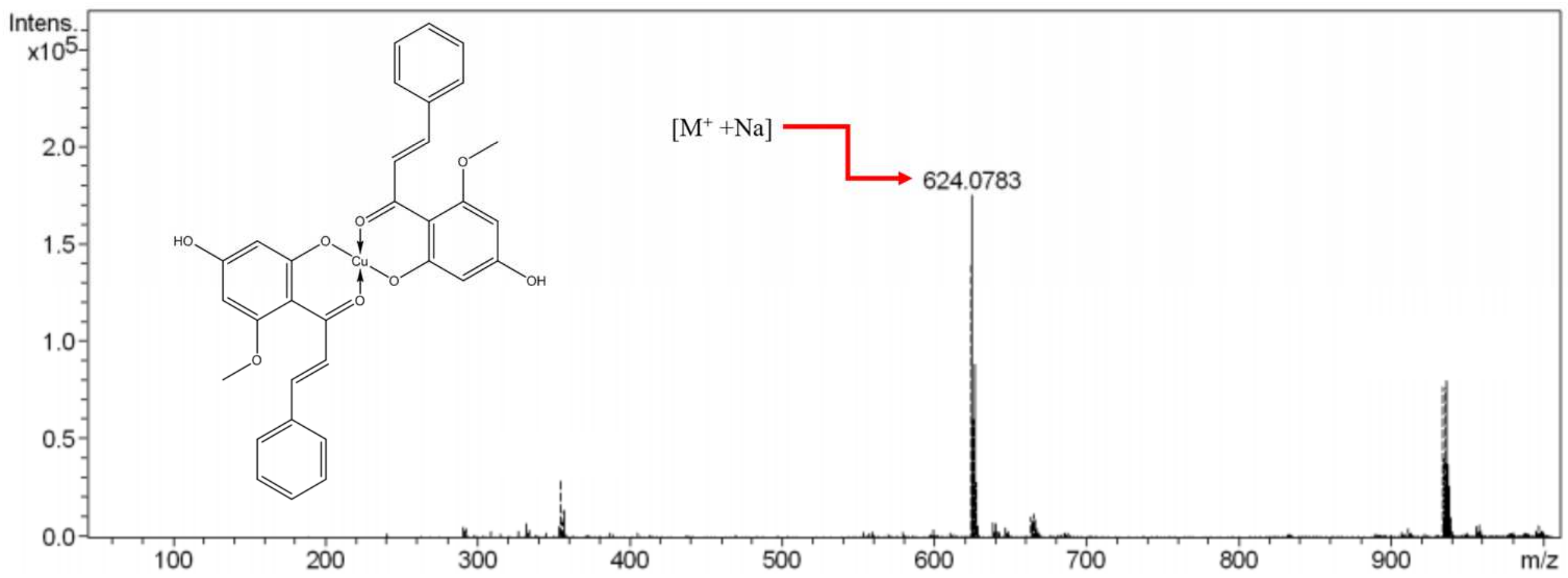

Figure 1. HRMS spectrum of 19. 
The IR spectrum of 19 showed a peak at around $1598 \mathrm{~cm}^{-1}$ assigned to $(\mathrm{C}=\mathrm{O})$ and this negative shift in the absorption frequency relative to that of cardamonin suggested coordination of the carbonyl oxygen with the metal ion. This negative shift is thought to be due to enhancement of the mesomeric effect upon complexation which results in lengthening of $(\mathrm{C}=\mathrm{O})$. Moreover, the peak assigned for 2'-OH at $3173 \mathrm{~cm}^{-1}$ has disappeared from the spectrum of $\mathbf{1 9}$ which indicates that the phenolic group has coordinated with the metal ion in its deprotonated form. This was further confirmed by the appearance of a peak at $1230 \mathrm{~cm}^{-1}$ which was assigned to the phenolic (C-O) of 19, and this positive shift further indicated the coordination of the phenolic oxygen of deprotonated 2'-OH to the metal ion.

NMR analysis for $\mathbf{1 9}$ resulted in a spectrum with low-intensity broad peaks and this was due to the paramagnetic nature of copper (II) ion (Figure 2). These broad peaks of 19 are actually an indication for the formation of the desired copper complex (19). The spectrum showed no peak for 2'-OH suggesting the involvement of the group's deprotonated form in complexation. Moreover, the peaks assigned to the aromatic protons of ring A (H-3' and $\mathrm{H}-5^{\prime}$ ') were found to be shifted downfield after complexation to $7.45 \mathrm{ppm}$ and $7.42 \mathrm{ppm}$, respectively. A slight downfield shift to $7.88 \mathrm{ppm}$ was also observed for H-7 after complexation. These downfield shifts observed were attributed to the electron withdrawing mesomeric effect exerted by $\mathrm{Cu}^{2+}$ after bonding with cardamonin's deprotonated 2'-OH and carbonyl oxygen. These characteristic peaks further prove the formation of $\mathbf{1 9}$ and provide further information about its structure. Table 2 summarizes the important IR and NMR peaks for compound 19.

Taken together, data amassed from the analytical techniques employed are consistent with the structure of 19 illustrated in Scheme 1. 
Table 2. Important IR and NMR peaks for cardamonin and compound 19

\begin{tabular}{|c|c|c|c|}
\hline & $\begin{array}{l}\text { Cardamonin } \\
\text { (Ligand) }\end{array}$ & $\begin{array}{c}\text { Compound } 19 \\
\text { (Metal Complex) }\end{array}$ & Structure inference for $\mathbf{1 9}$ \\
\hline \multirow[t]{2}{*}{ IR $\left(\mathrm{cm}^{-1}\right)$} & $1630(\mathrm{C}=\mathrm{O})$ & $1598(\mathrm{C}=\mathrm{O})$ & $\begin{array}{l}\text { Negative shift in the } \\
\text { absorption } \\
\text { indicates that }(\mathrm{C}=\mathrm{O}) \\
\text { coordinates with the metal } \\
\text { ion }\end{array}$ \\
\hline & $3170\left(2^{\prime}-\mathrm{OH}\right)$ & -- & $\begin{array}{l}\text { Deprotonated 2'-OH } \\
\text { participates in forming the } \\
\text { metal complex }\end{array}$ \\
\hline
\end{tabular}

\begin{tabular}{|c|c|c|c|}
\hline \multirow[t]{3}{*}{${ }^{1} \mathrm{H}-\mathrm{NMR}$ (ppm) } & $\begin{array}{l}\text { Sharp peaks of } \\
\text { high intensity }\end{array}$ & $\begin{array}{l}\text { Broad peaks of } \\
\text { low intensity }\end{array}$ & $\begin{array}{l}\text { The paramagnetic nature of } \\
\mathrm{Cu}^{2+} \text { causes the NMR peaks } \\
\text { to broaden and have low } \\
\text { intensities. This by itself } \\
\text { proves the formation of the } \\
\text { metal complex }\end{array}$ \\
\hline & $\begin{array}{c}5.92\left(\mathrm{H}-5^{\prime}\right) \\
6.02\left(\mathrm{H}^{\prime}{ }^{\prime}\right) \\
7.83(\mathrm{H}-7)\end{array}$ & $\begin{array}{l}7.42\left(\mathrm{H}-5^{\prime}\right) \\
7.45\left(\mathrm{H}^{\prime} 3^{\prime}\right) \\
7.88(\mathrm{H}-7)\end{array}$ & $\begin{array}{l}\text { Downfield shift for the } \\
\text { protons of ring } \mathrm{A} \text { and } \mathrm{H}-7 \text { as } \\
\text { a result of the coordination } \\
\text { of }(\mathrm{C}=\mathrm{O}) \text { and deprotonated } \\
\text { 2'-OH with the metal ion }\end{array}$ \\
\hline & $13.69\left(2^{\prime}-\mathrm{OH}\right)$ & -- & $\begin{array}{l}\text { Deprotonated } 2 \text { '-OH } \\
\text { participates in forming the } \\
\text { metal complex }\end{array}$ \\
\hline
\end{tabular}



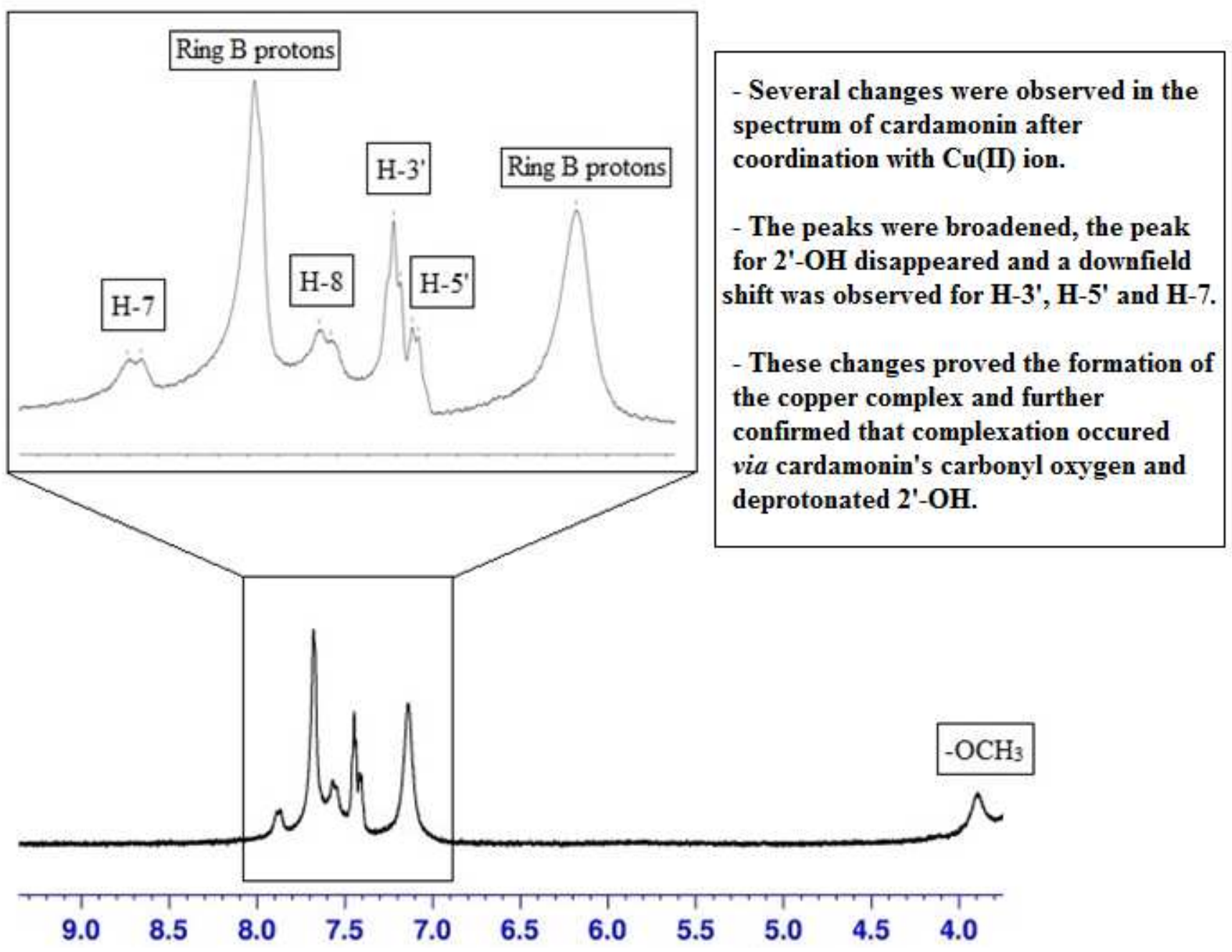

Figure 2. Magnified NMR spectrum of 19. The paramagnetic nature of $\mathrm{Cu}$ (II) caused the NMR peaks to broaden and decrease in intensity. 


\subsection{Biological studies}

\subsubsection{Cell viability and SAR studies}

Table 3. $\mathrm{IC}_{50}$ values of cardamonin and its analogues against HK1 and A549 cells

\begin{tabular}{|c|c|c|}
\hline \multirow[b]{2}{*}{ Compound } & \multicolumn{2}{|c|}{$\mathrm{IC}_{50}(\mu \mathrm{M})^{\mathrm{a}}$} \\
\hline & A549 & HK1 \\
\hline Cardamonin & $67.0 \pm 7.0$ & $22.6 \pm 5.4$ \\
\hline (1) & $>100$ & $>100$ \\
\hline (2) & $35.1 \pm 9.9$ & $4.95 \pm 0.9$ \\
\hline (3) & $>100$ & $>100$ \\
\hline (4) & $27.3 \pm 4.3$ & $21.7 \pm 5.9$ \\
\hline (5) & $>100$ & $89.5 \pm 7.1$ \\
\hline (6) & $37.6 \pm 3.1$ & $29.4 \pm 1.1$ \\
\hline (7) & $>100$ & $>100$ \\
\hline (8) & $>100$ & $>100$ \\
\hline (9) & $>100$ & $>100$ \\
\hline (10) & $23.9 \pm 5.7$ & $36.6 \pm 14.2$ \\
\hline (11) & $63.8 \pm 6.5$ & $46.8 \pm 10.3$ \\
\hline (12) & $>100$ & $>100$ \\
\hline (13) & $29.9 \pm 1.3$ & $66.5 \pm 3.3$ \\
\hline (14) & $>100$ & $>100$ \\
\hline (15) & $36.1 \pm 1.3$ & $49.7 \pm 3.6$ \\
\hline (16) & $>100$ & $>100$ \\
\hline (17) & $>100$ & $>100$ \\
\hline (18) & $83.9 \pm 16.2$ & $60.4 \pm 3.7$ \\
\hline (19) & $13.2 \pm 4.8$ & $0.7 \pm 0.3$ \\
\hline
\end{tabular}

${ }^{\mathrm{a}} \mathrm{IC}_{50}$ values are reported as the mean $\left(\mathrm{IC}_{50} \pm \mathrm{SEM}\right)$ of duplicates of 3 independent experiments. 
Results of the bioassay are summarized in Table 3, and analogues demonstrating activities higher than cardamonin were regarded as active. Overall, the active analogues were several fold more potent than cardamonin (up to 32 times more potent). Compound 19 demonstrated the highest activity followed by compound $\mathbf{2}$. Therefore, the results identified compounds $\mathbf{1 9}$ and $\mathbf{2}$ as the most promising analogues, and simultaneously reflected the high potential of the other active analogues as potent anticancer compounds.

SAR analysis revealed that generally substituting cardamonin's hydroxyl groups with nonpolar groups resulted in loss of cytotoxic activity, while substitution with more polar groups enhanced activity. This was deduced primarily by comparing the bioactivities of $\mathbf{1}, \mathbf{2}, \mathbf{3}$ and $\mathbf{4}$, whereby there was a loss in activity when the hydroxyl groups were methylated and benzylated, but acetylation of the same groups and allylation of 4'-OH resulted in activity enhancement. However, it seems that loss of activity upon $O$-benzylation might not be due to polarity alone, as activity was also lost when the hydroxyl groups were substituted by the more polar 4fluorobenzoyl group. Therefore, it has been suggested that steric hindrance could be the main reason behind the loss of activity for $\mathbf{3}$ and $\mathbf{5}$, preventing any potential interactions between the ketone group and the receptor. This steric hindrance effect does not seem to exist when only benzoylation of 4'-OH occurred as in analogue 6, whereby activity was enhanced in A549 cells. Thus, it can be concluded that avoiding bulky substituents at cardamonin's 2'-OH and substituting the hydroxyl groups with more polar fragments is expected to enhance bioactivity.

There was a significant loss in the cytotoxic activity of $\mathbf{7}$ and $\mathbf{1 7}$ which lacked the alkene double bond; these results suggest that the alkene double bond is crucial for bioactivity. Importance of the ketone group to bioactivity was investigated by Schiff base formation and cyclization reactions at the group. Results have shown that Schiff bases of cardamonin, $\mathbf{8}$ and $\mathbf{9}$, had no bioactivity while only the SBDTC-derived analogue, 10, retained activity but it was not considered due to its low purity. Furthermore, 11, 12 and 14 were generally found to have no activity indicating that cyclization at the ketone group also results in loss of activity. However, 13 was an exception, whereby high activity was demonstrated against A549 cells despite chemical modification at cardamonin's ketone group, and this activity was attributed to the formation of a pyrimidinone moiety as a result of the tautomerization of $\mathbf{1 3}$ at its target receptor; thus the analogue would still possess a ketone group in this case resulting in enhanced activity. Therefore, it can generally be concluded that cardamonin's alkene double bond and its ketone group are crucial, as their absence led to a loss in activity.

Halogenation of cardamonin resulted in compounds 15 and 16. The good bioactivity of 15 showed that iodination of cardamonin enhanced bioactivity, however, bromination resulted in loss of activity as can be seen in 16. 18 demonstrated very weak bioactivity, but it has been suggested that the compound could act as an antioxidant for due to its high phenolic content.

The copper complex of cardamonin (19) showed highly potent activity and was the most active analogue with interesting $\mathrm{IC}_{50}$ values of $13.2 \mu \mathrm{M}$ and $0.7 \mu \mathrm{M}$ against $\mathrm{A} 549$ and HK1 cells respectively, demonstrating an enhancement in activity of 5- and 32-fold relative to cardamonin, respectively. These results indicate that complexation of cardamonin to metal ions could enhance activity. Figure 3 summarizes the results of the SAR study 


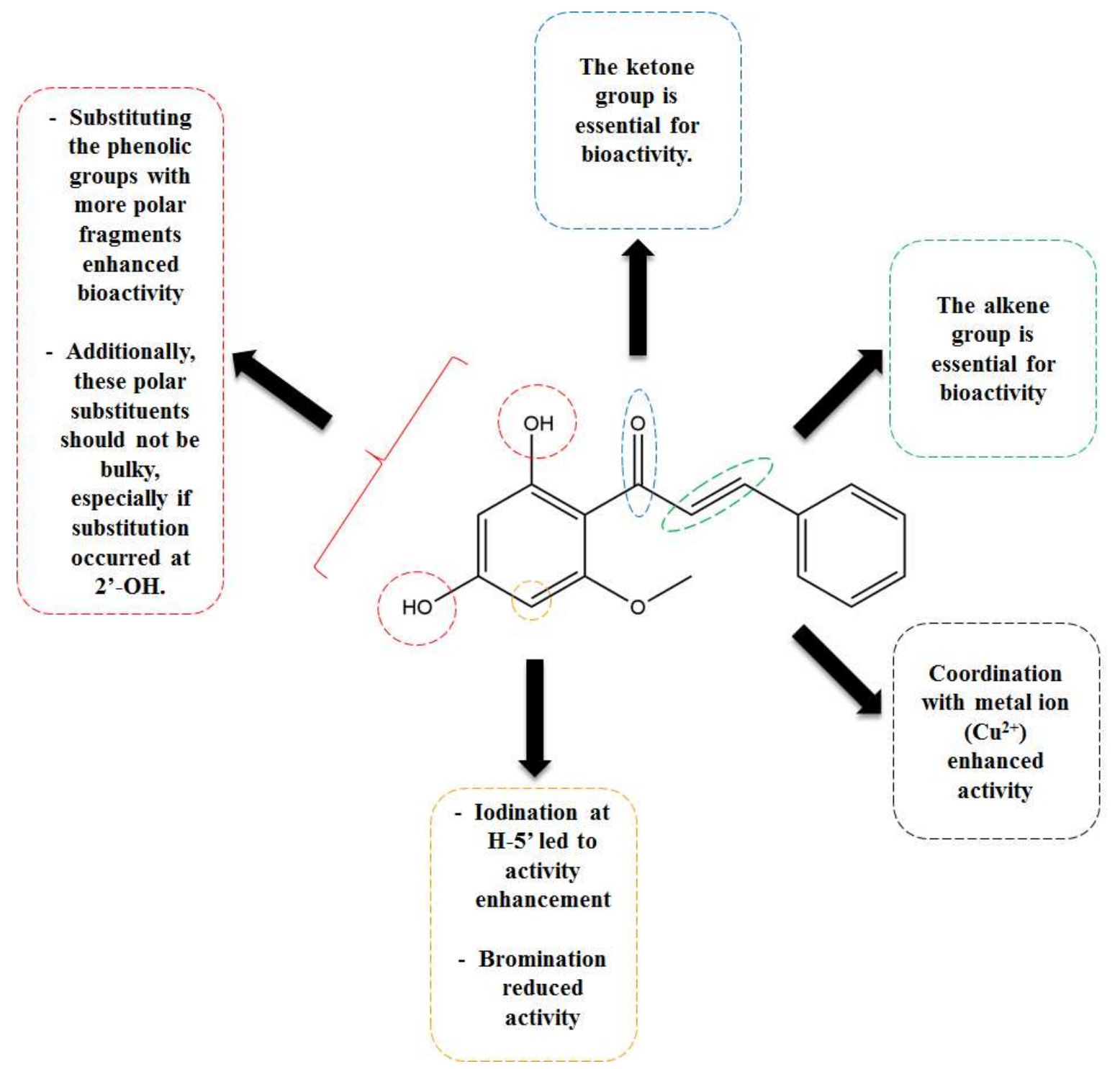

Figure 3. A summary of the SAR study of cardamonin analogues 


\subsubsection{Active analogues showed more selectivity towards cancer cells}

In order to determine the selectivity of the active analogues for cancer cells, the bioactive analogues were further screened against human normal lung fibroblasts (MRC-5) (Table 4). The results showed that almost all active analogues showed greater selectivity towards the cancer cell lines and demonstrated lower cytotoxicity towards the normal MRC-5 fibroblasts. Of particular note is the highly bioactive compound 19, which was almost 29 times more selective towards HK1 cells. Such data further corroborated the potential of $\mathbf{1 9}$ as an anticancer agent and encouraged its further investigation.

Table 4. Cytotoxic activity of the bioactive analogues against MRC-5 cells

\begin{tabular}{cccc}
\hline \multirow{2}{*}{ Compound } & $\begin{array}{c}\text { SClectivity index }(\mathrm{SI})^{\mathrm{b}} \\
(\mathrm{MRC}-5)\end{array}$ & $\mathrm{A})^{\mathrm{a}}$ & $\mathrm{HK} 1$ \\
\cline { 3 - 4 }$(\mathbf{2})$ & $17.1 \pm 4.2$ & 0.5 & 3.5 \\
$(\mathbf{4})$ & $39.9 \pm 7.8$ & 1.5 & 1.8 \\
$(\mathbf{6})$ & $>100$ & $\mathrm{NA}$ & $\mathrm{NA}$ \\
$(\mathbf{1 3})$ & $>100$ & $\mathrm{NA}$ & $\mathrm{NA}$ \\
$(\mathbf{1 5})$ & $>100$ & $\mathrm{NA}$ & $\mathrm{NA}$ \\
(19) & $20.6 \pm 3.3$ & 1.6 & 28.6
\end{tabular}

${ }^{\mathrm{a}} \mathrm{IC}_{50}$ values are reported as the mean $\left(\mathrm{IC}_{50} \pm \mathrm{SEM}\right)$ of duplicates of 3 independent experiments.

${ }^{\mathrm{b}} \mathrm{SI}=\left(\mathrm{IC}_{50}\right.$ of MRC-5)/(IC 50 of A549 or HK1 $)$. 


\subsubsection{Compound 19 inhibited cancer cell migration}

A wound healing scratch assay was implemented in order to investigate the effect of $\mathbf{1 9}$ on the migration of A549 and HK1 cells and compare it to that of cardamonin (Figure 4). Compared with the control treatment, $\mathbf{1 9}$ has significantly reduced the migration of A549 and HK1 cells by around 2-fold and >3-fold, respectively. Furthermore, the inhibitory effect of $\mathbf{1 9}$ on the migration of both cell lines was generally 2-3 times stronger than that of cardamonin, which further highlights the enhanced bioactivity possessed by 19 . 
A
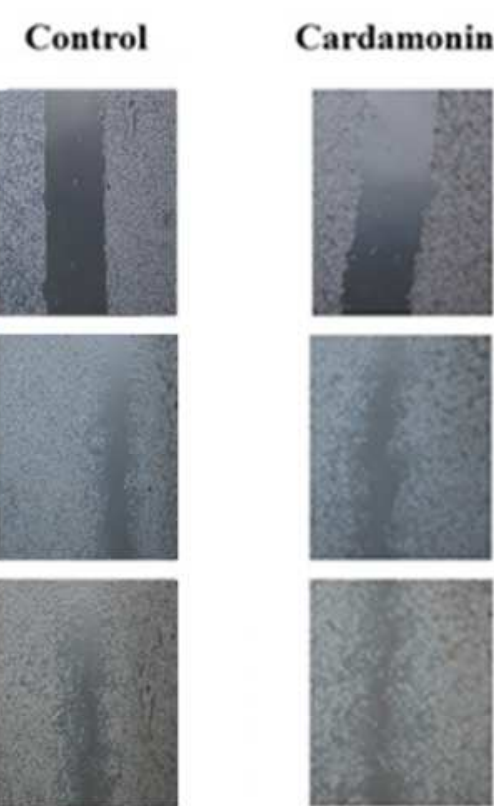

$\mathrm{t}=\mathbf{2 4 h}$

$t=48 h$
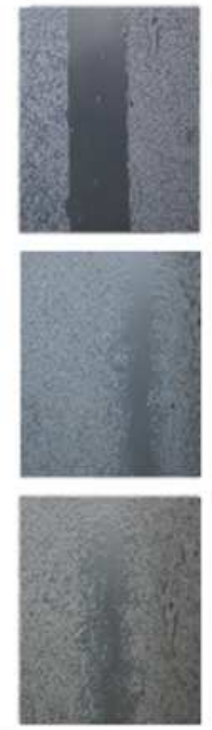

C

Control

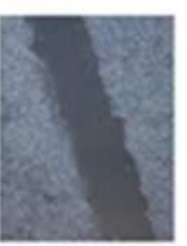

HKl

$t=\mathbf{2 4 h}$

$t=48 h$

Cardamonin

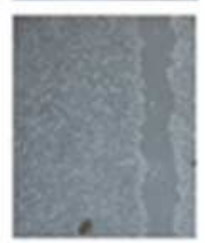

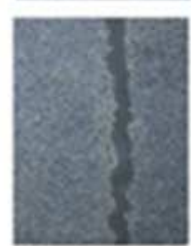

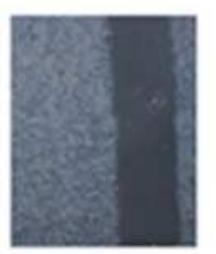

Compound 19
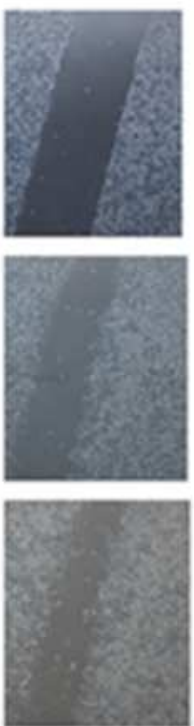

B

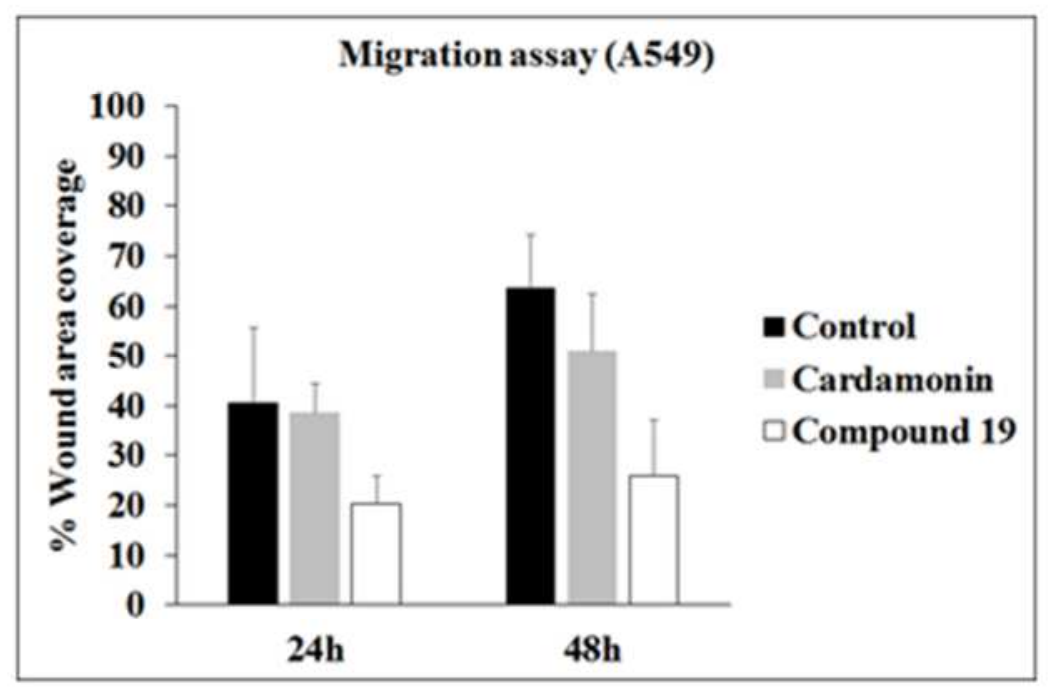

D

Compound 19
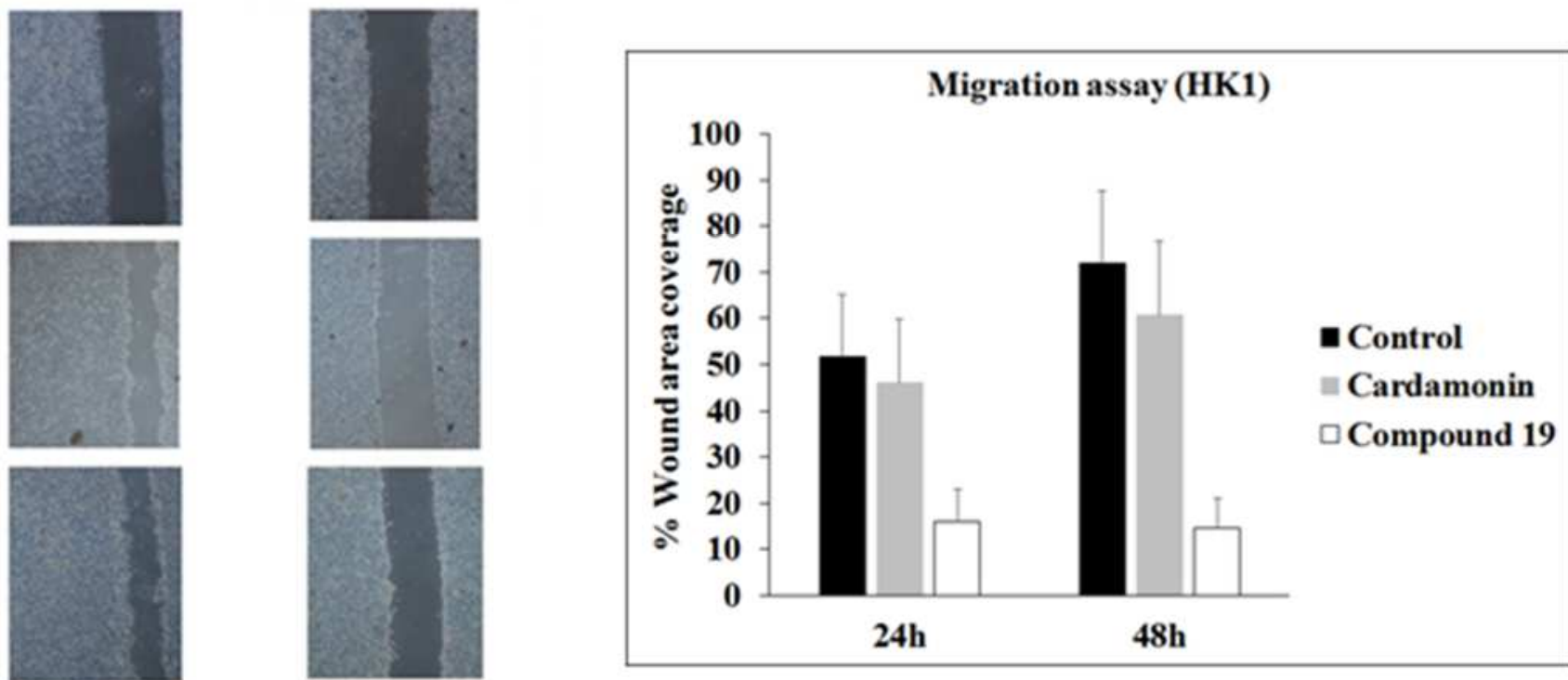
Figure 4. Compound 19 inhibited the migration of A549 and HK1 cells. (A and C) Migration assay was conducted in a 6-well plate by forming a "wound" across a layer of cells followed by treatment with either solvent control, $25 \mu \mathrm{M}$ cardamonin or $25 \mu \mathrm{M}$ compound 19 . The figure shows representative wound closure images from three experiments. (B and D) Cell migration was calculated and expressed as the percentage of "wound" area covered by the cells to the initial cell-free "wound" area. Results represent the mean \pm SEM of 3 independent experiments. 


\subsubsection{Induction of G2/M-phase arrest by compound 19 in A549 and HK1 cells}

Cell-cycle is the series of events that occur in order to enable cell division and replication, and consists of four distinct phases: G1-phase which involves the preparation of material and energy for replication, S-phase (synthesis) where DNA replication occurs, G2-phase (interphase) where the new replicated DNA is checked and errors are repaired, and $\underline{\mathrm{M} \text {-phase }}$ (mitosis) which involves the nuclear and cytoplasmic division of the cell [14].

A549 and HK1 cells treated with 19 for 24 h showed a profound increase in the fraction of cells in the G2/M-phase (37.38\% compared to $10.52 \%$ in the untreated cells for A549 cells; $39.15 \%$ compared to $15.48 \%$ in the untreated cells for HK1 cells). This was accompanied by a decrease in the number of cells in the G1-phase for both cell lines and S-phase for A549 only (Figure 5). Therefore, this indicated that 19 induced G2/M-phase cell-cycle arrest in both A549 and HK1 cells.

$\underline{\mathrm{A549}}$

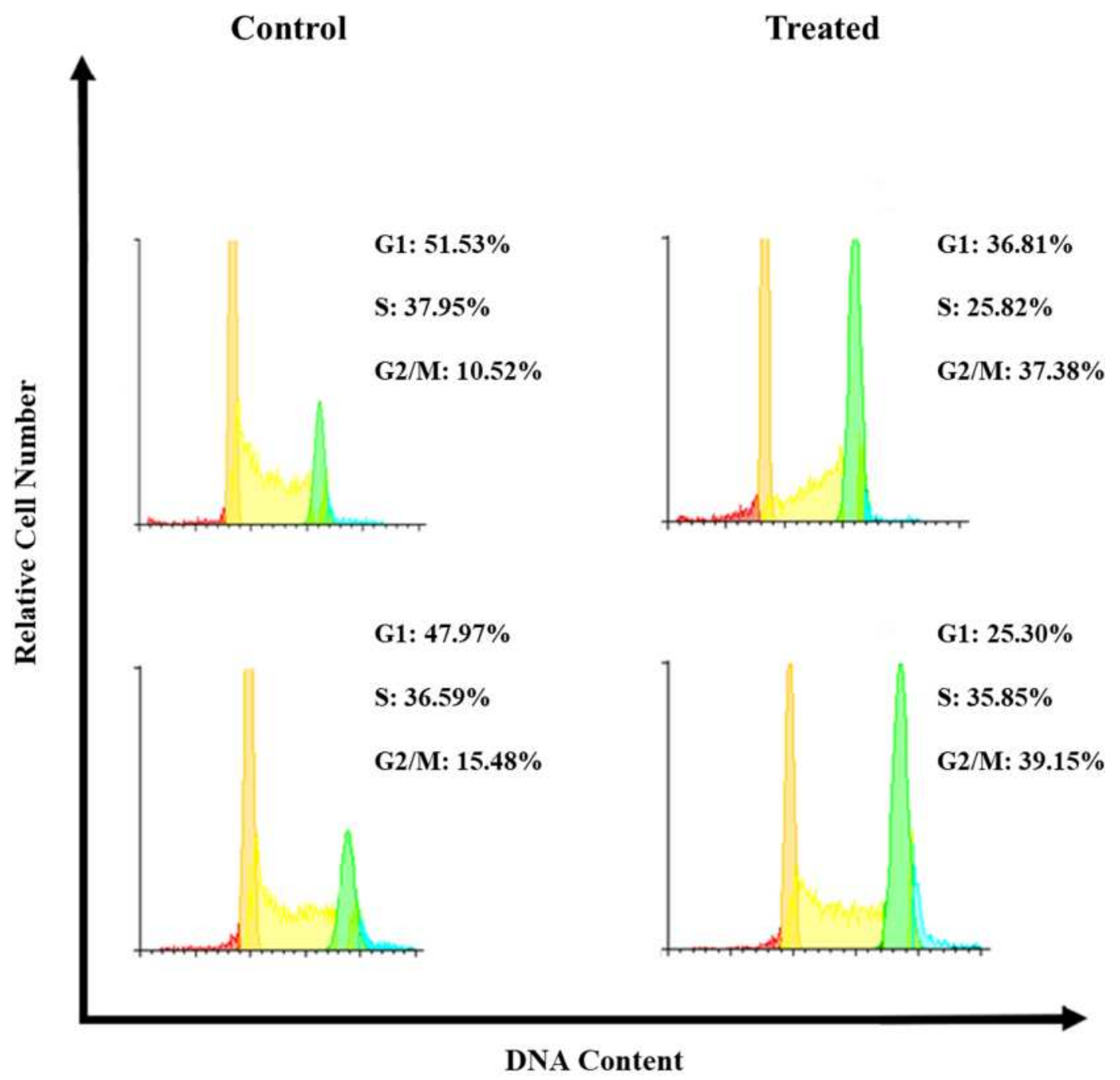

Figure 5. Flow cytometric analysis of cell-cycle parameters following $24 \mathrm{~h}$ of treatment with 19 at $\mathrm{IC}_{50}$ concentrations in A549 and HK1 cells. Data were gated to exclude apoptotic cells from calculations of the fraction of cells in G1, S and G2/M phases. Results are representative of 2 independent experiments for each cell-line. 


\subsubsection{Compound 19 causes DNA damage in A549 and HK1 cells}

Cell-cycle arrest at G2/M phase is a common cellular response for agents that cause DNA damage [15], and since 19 induced a G2/M-phase cell cycle arrest, we reasoned that it might be able to cause DNA damage. DNA damage that results in the formation of double-strand breaks (DSB) is always followed by phosphorylation of the histone $\mathrm{H} 2 \mathrm{AX}$ to $\gamma-\mathrm{H} 2 \mathrm{AX}$ [16]. Therefore, $\gamma-\mathrm{H} 2 \mathrm{AX}$ is considered a DNA double-strand breaks (DSB) marker which can be quantified in order to assess DNA damage.

The induction of DNA damage by 19 was assessed by detecting the number of cells expressing $\gamma-\mathrm{H} 2 \mathrm{AX}$ after treatment. Flow cytometry was used to detect $\gamma-\mathrm{H} 2 \mathrm{AX}$ formation. As demonstrated in Figure 6, 19 significantly increased the formation of $\gamma$-H2AX in A549 and HK1 cells by 7- and 5-fold relative to the control, respectively. This indicated that the anticancer activity of $\mathbf{1 9}$ involved the induction of DNA damage in both cell lines as has been predicted. 

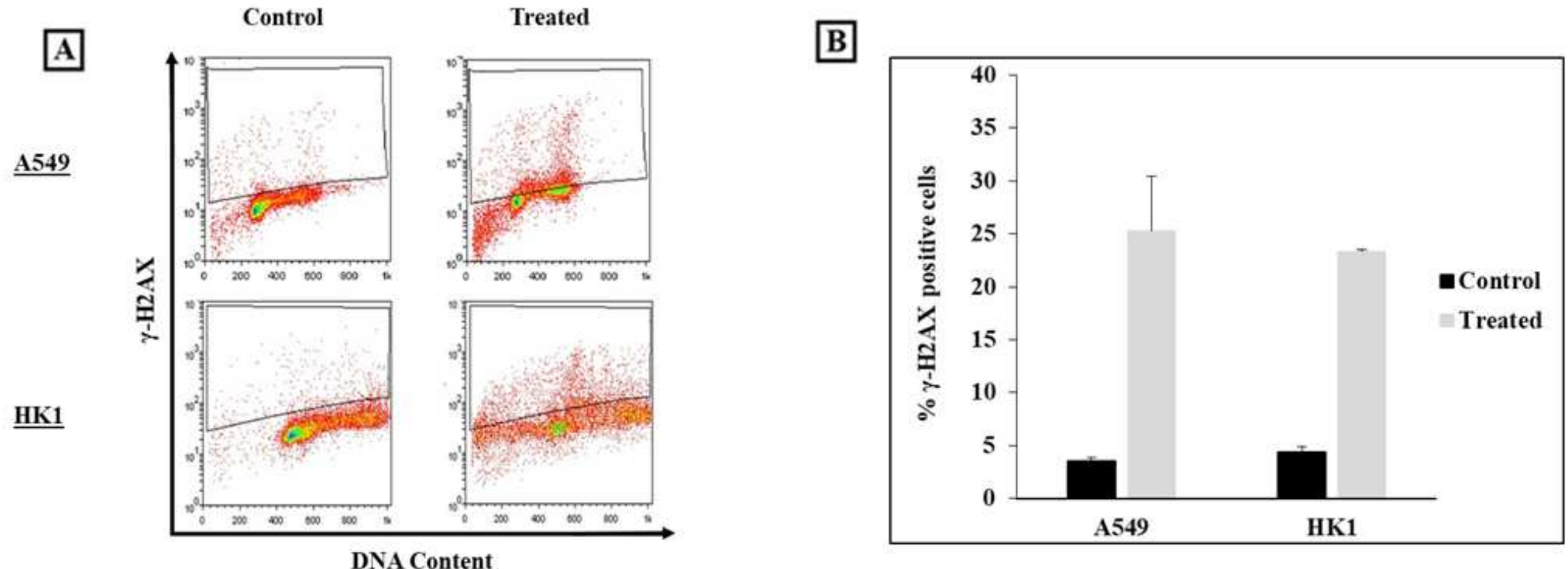

Figure 6. Flow cytometric detection of $\gamma$-H2AX formation following $24 \mathrm{~h}$ of treatment with $\mathbf{1 9}$ at $\mathrm{IC}_{50}$ concentrations in A549 and $\mathrm{HK} 1$ cells. (A) Representative dot-plots illustrating $\gamma$-H2AX abundance versus total cellular DNA content of each cell. (B) Bar chart summarizing results of the flow cytometry analysis. Results represent the mean \pm SEM of 2 independent experiments. 


\subsubsection{Induction of apoptosis by compound 19 via the activation of caspase-3/7 and caspase-}

9, cleavage of PARP and downregulation of Mcl-1

The activation of caspases is considered to be the hallmark of apoptosis, especially caspase-3 which is considered to be the most important of the executioner caspases. It is activated by any of the initiator caspases which results in direct activation of enzymes responsible for DNA fragmentation [17]. Caspase-8 and caspase-9 are initiator caspases that activate caspase-3 via the extrinsic and intrinsic (mitochondrial) apoptotic pathways, respectively [18].

Therefore, the induction of apoptosis by the most active compound, 19, in A549 and HK1 cells was investigated via a Caspase-Glo 3/7, 8 and 9 Assay. Results of the assay showed that A549 and HK1 cells treated with 19 led to the activation of caspase-9 and caspase-3/7 (Figure 7). This suggested that 19 induced caspase-dependent apoptosis via the intrinsic (mitochondrial) pathway.

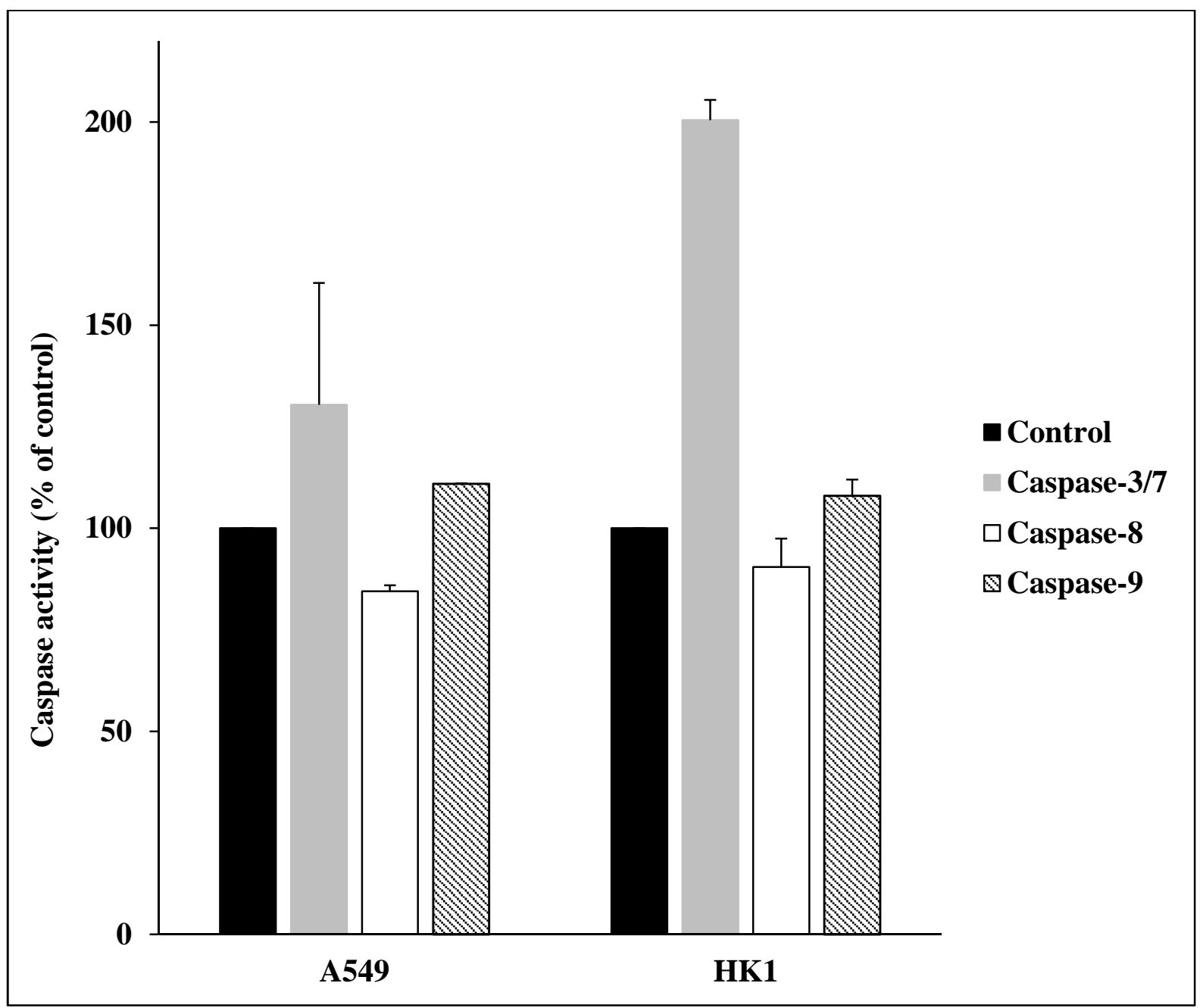

Figure 7. Caspase-3/7, caspase- 8 and caspase- 9 activity of A549 cells and HK1 cells, treated with 19 at $\sim 10 \mu \mathrm{M}$. The experiments were performed in duplicate for each cell line, and bars and error bars refer to mean \pm SEM. 
Expression levels of other apoptosis-related proteins, such as PARP and Mcl-1, were also investigated by Western blotting in order to further understand the mechanism by which 19 induces apoptosis. PARP is a caspase-3 substrate that has roles in DNA repair, cell survival and apoptosis, while Mcl-1 is an anti-apoptotic protein. Results of Western blot analysis showed that 19 resulted in the cleavage of PARP and downregulation of Mcl-1 in A549 and HK1 cells (Figure 8). These Western blot results provide further evidence that compound 19 induces apoptosis in both cell lines.

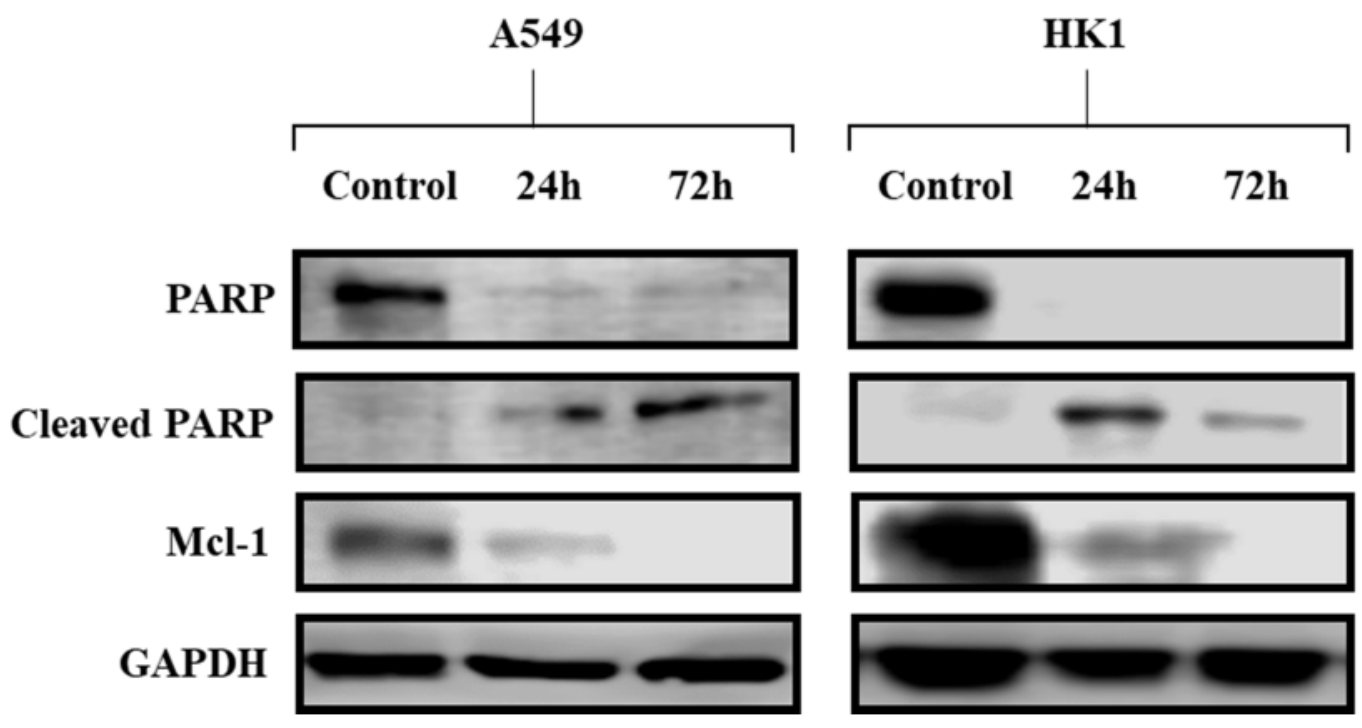

Figure 8. Western blot analysis of PARP and Mcl-1 in A549 and HK1 cells. Cells were treated with $25 \mu \mathrm{M}$ of 19 for $24 \mathrm{~h}$ and $72 \mathrm{~h}$. GAPDH was used as an internal control 


\subsubsection{Compound 19 inhibited the mTOR pathway}

The mammalian target of rapamycin (mTOR) pathway is commonly activated in several types of cancers and regulates cell proliferation, metabolism, survival and metastasis. Several previous studies stated that cardamonin exerted its cytotoxic effect via mTOR inhibition [1921]. Therefore, it was decided to investigate whether the most active analogue, 19, also exerted its anticancer effect via mTOR signal transduction inhibition. This was done by Western blot analysis of the expression levels of phosphorylated mTOR (p-mTOR), phosphorylated 4EBP1 (p-4EBP1) and their total proteins. 4EBP1 is the first downstream substrate of mTOR, and its phosphorylation by mTOR promotes protein synthesis.

Western blot analysis (Figure 9) showed that compound 19 managed to downregulate the expression levels of p-mTOR, and p-4EBP1 in A549 and HK1 cells. This indicated that 19 exerted its anticancer effect, at least in part, via inhibition of the mTOR pathway.

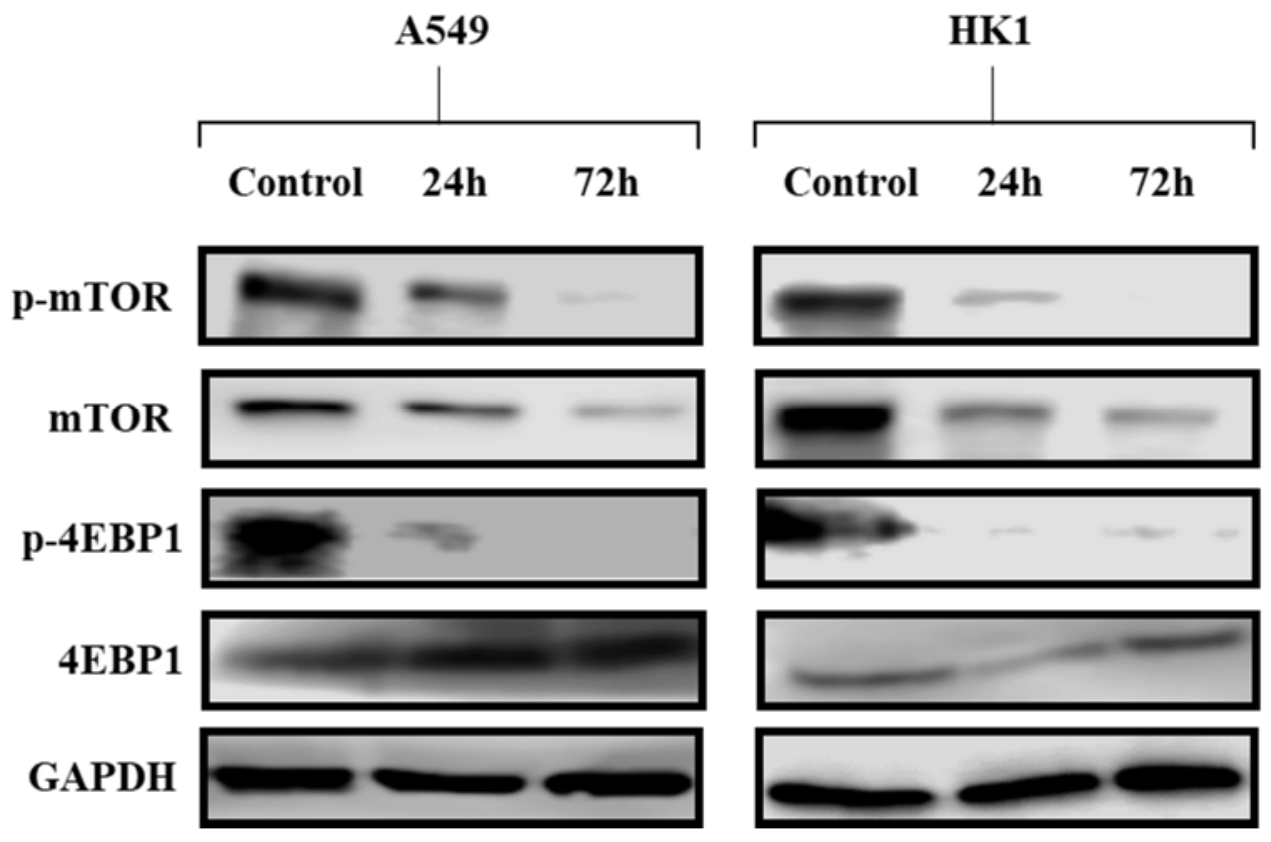

Figure 9. Western blot analysis of p-mTOR, total mTOR, p-4EBP1 and total 4EBP1 in A549 and HK1 cells. Cells were treated with $25 \mu \mathrm{M}$ of 19 for $24 \mathrm{~h}$ and $72 \mathrm{~h}$. GAPDH was used as an internal control

The effect of 19 on mTOR signalling was further assessed via qPCR analysis. Results of the assay showed that 19 downregulated the expression of mTOR by $>50 \%$ (Figure 10). This further proved the inhibitory effect of $\mathbf{1 9}$ on mTOR signal transduction. 


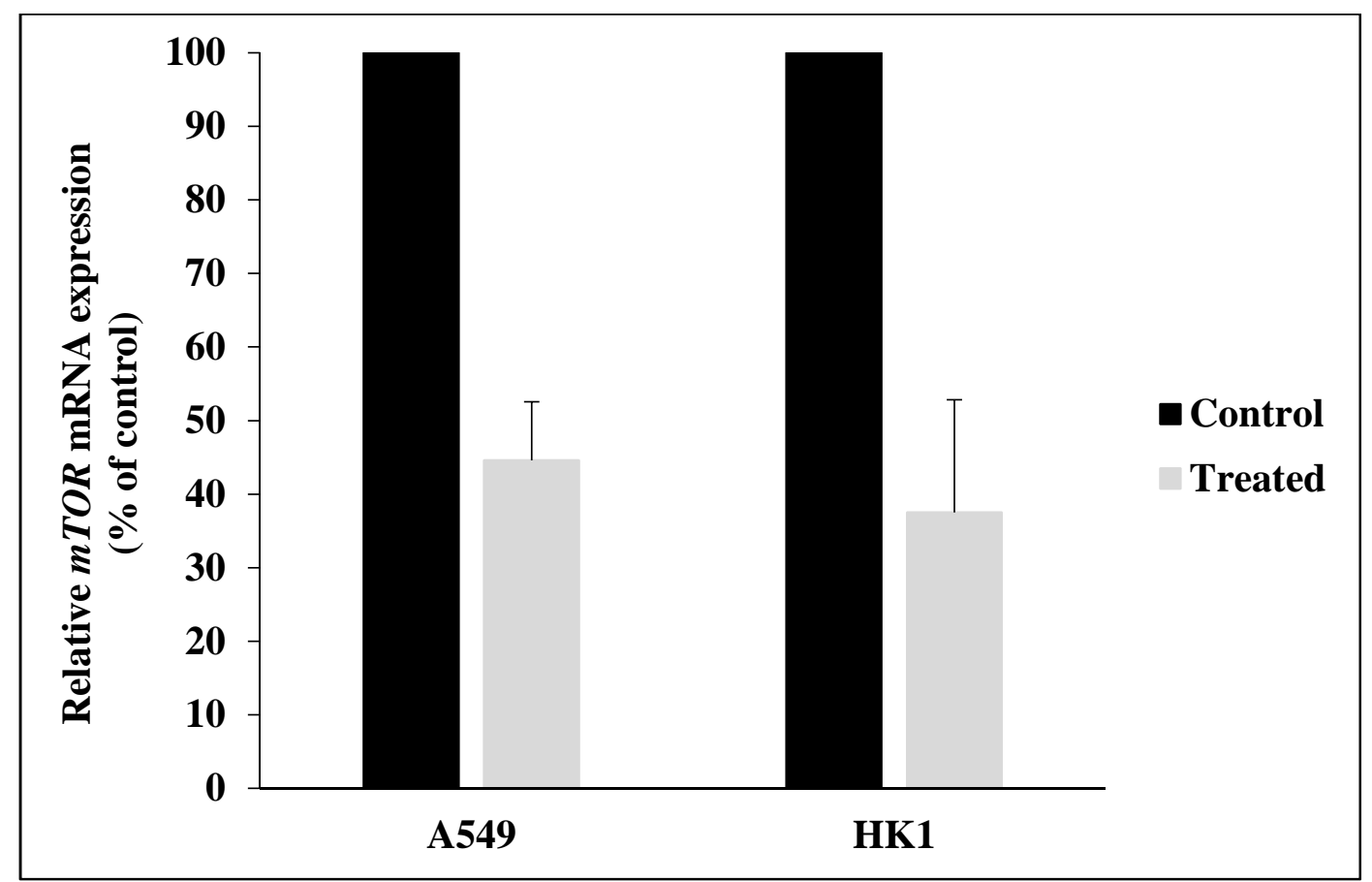

Figure 10. mRNA expression of $m T O R$ in A549 and HK1 cells after treatment with $50 \mu \mathrm{M}$ of compound 19 for $24 \mathrm{~h}$, as determined by qPCR. mRNA expression levels were normalized to GAPDH and compared with the untreated control. Mean \pm SEM of 3 independent qPCR experiments are shown. 


\section{Conclusion}

In the present study, 19 analogues of cardamonin were semi-synthesized and their activity tested against A549 and HK1 cell lines. The chemistry and reactivity of cardamonin has been explored together with SAR analysis for the first time. However, the main contribution of this study is in the discovery of the highly active copper (II) complex of cardamonin (19). Compound 19 demonstrated potent activity against A549 and HK1 cell lines with $\mathrm{IC}_{50}$ values of $13.2 \mu \mathrm{M}$ and $0.7 \mu \mathrm{M}$, respectively, while also showing higher selectivity towards the cancer cell lines. It also significantly inhibited the migration of cancer cells. Further studies revealed that 19 induced DNA damage and G2/M-phase cell-cycle arrest which resulted in caspasedependent apoptosis via the mitochondrial pathway. Moreoever, 19 inhibited mTOR signal transduction. Figure 10 summarizes the proposed signalling pathway triggered by $\mathbf{1 9}$ in the cancer cells. To the best of our knowledge this is the first study that attempted to optimize the bioactivity of cardamonin and explore its SAR, chemistry and reactivity further. Such groundwork will guide future optimization studies on cardamonin and possibly other structurally related chalcones. 


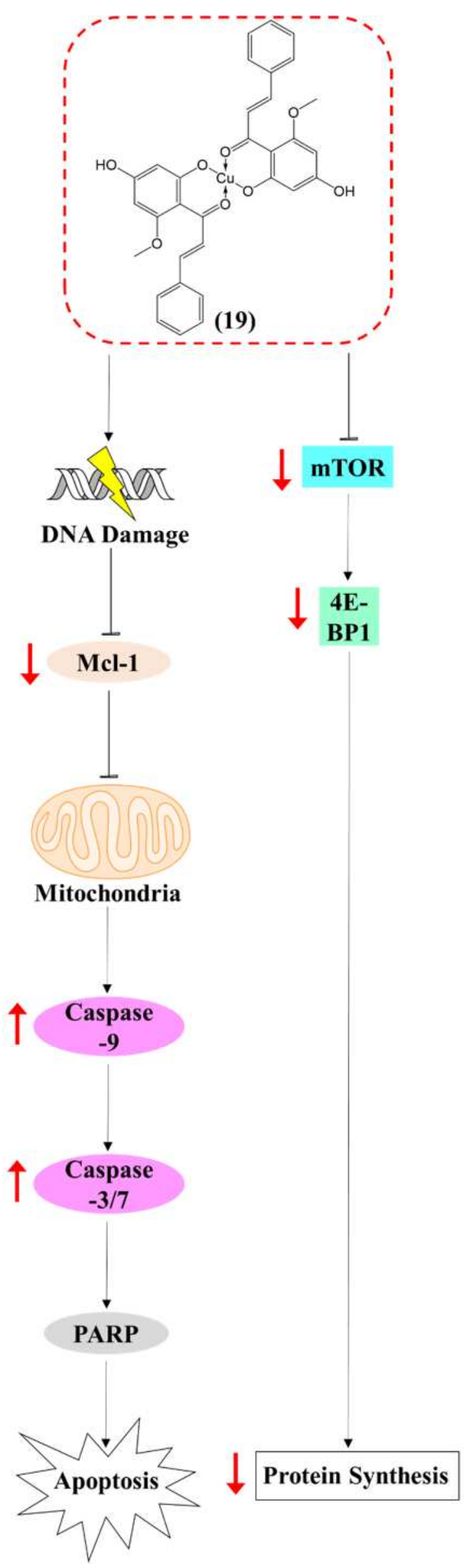

Figure 10. Schematic representation of the proposed signalling pathways induced by 19 in cancer cells 


\section{Materials and methods}

\subsection{General}

Reagents of analytical grade were used as received from their commercial sources, while cardamonin (98\% purity) was obtained from Shanghai Yuanye Bio-Technology Co. Ltd (Shanghai, China). Elemental analysis was performed on a Vario MACRO CUBE CHNS analyzer, while thermogravimetric analysis (TGA) was performed via a Mettler Toledo TGA analyser up to $800^{\circ} \mathrm{C}$ with a heating rate of $10^{\circ} \mathrm{C} / \mathrm{min}$ in an atmosphere of $\mathrm{N}_{2}$. IR spectra were recorded by a Perkin Elmer FTIR spectrophotometer within the range (4000-400 $\mathrm{cm}^{-1}$ ) using $\mathrm{KBr}$ discs while melting points have been measured using an Electrothermal IA9100 digital m.p. apparatus measuring within a range of $\left(0{ }^{\circ} \mathrm{C}-400{ }^{\circ} \mathrm{C}\right)$. HPLC purity analysis was performed using an Agilent 1260 Infinity system equipped with a Zorbax 300SB-C18 column ( $5 \mu \mathrm{m}, 250 \mathrm{~mm} \times 4.6 \mathrm{~mm}$ ). Mobile solvent A was water, while B was acetonitrile and the flow rate used was $1.25 \mathrm{ml} / \mathrm{min}$ The time program used for the HPLC analysis was $55 \% \mathrm{~B}$ (0-5 min), $55 \%-85 \%$ B (5-25 min) and 99\% B (25-30 min).

${ }^{1} \mathrm{H}$ NMR spectra were obtained via a Bruker FT-NMR $300 \mathrm{MHz}, 400 \mathrm{MHz}$ and $600 \mathrm{MHz}$. TLC was performed using 60F aluminium silica gel aluminium plates with $254 \mathrm{~nm}$ fluorescent indicator from Merck. UV-Vis spectra were obtained via an UltroSpec 8000 spectrophotometer.

\subsection{Synthesis}

\section{Cardamonin}

IR $\left(\mathrm{KBr}, \mathrm{cm}^{-1}\right)$ : 3448, 3173 (2'-OH), $2926(\mathrm{C}-\mathrm{H}), 1630(\mathrm{C}=\mathrm{O}), 1609$ and 1475(aromatic C=C), 1384, 1225 and 1212 (phenolic C-O), $1112\left(\mathrm{O}_{-} \mathrm{CH}_{3}\right), 972,790,744 ;{ }^{1} \mathrm{H}$ NMR (300 MHz, DMSO, $\delta(\mathrm{ppm})): 13.69$ (s, 1H, 2'-OH), 7.83 (d, 1H, H-7, $J=15.6 \mathrm{~Hz}), 7.65$ (d, 1H, H-8, $J=$ $15.9 \mathrm{~Hz}), 7.73-7.44(\mathrm{~m}, 5 \mathrm{H}$, aromatic protons of ring B), $6.02(\mathrm{~d}, 1 \mathrm{H}, \mathrm{H}-3$ ', $J=2.1 \mathrm{~Hz}), 5.92$

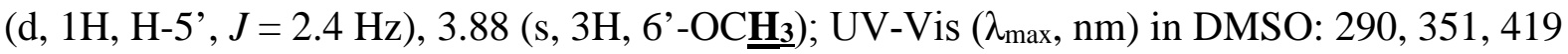

General method for synthesis of (1), (2) and (3)

Cardamonin ( $30 \mathrm{mg}, 0.11 \mathrm{mmol}$ ) was dissolved in acetone followed by the addition of $\mathrm{K}_{2} \mathrm{CO}_{3}$ $(0.14 \mathrm{~g}, 1 \mathrm{mmol})$. The alkyl halide was later added and the reaction mixture was left to stir under reflux for $24 \mathrm{~h}$. $\mathrm{K}_{2} \mathrm{CO}_{3}$ was removed by filtration while the solvent was evaporated in vacuo. The remaining solid was finally purified via preparative TLC using a mobile phase of cyclohexane:choroform in a ratio of 6:4.

The alkyl halides used were methyl iodide $(2 \mathrm{ml}, 0.032 \mathrm{~mol})$, allyl bromide $(0.2 \mathrm{ml}, 2.31 \mathrm{mmol})$ and $\mathrm{BnCl}(2 \mathrm{ml}, 0.017 \mathrm{~mol})$ for the synthesis of (1), (2) and (3), respectively. 
Yield: $7.4 \mathrm{mg}$; Mp: 55-61 ${ }^{\circ} \mathrm{C}$; IR $\left(\mathrm{KBr}, \mathrm{cm}^{-1}\right)$ : 3449, $2938(\mathrm{C}-\mathrm{H}), 1633(\mathrm{C}=\mathrm{O}), 1606$ and 1458 (aromatic $\mathrm{C}=\mathrm{C}$ ), 1336, 1228 (phenolic $\mathrm{C}-\mathrm{O}$ ), $1128\left(\mathrm{O}_{-} \mathrm{CH}_{3}\right), 974,815,742 ;{ }^{1} \mathrm{H}$ NMR $\left(400 \mathrm{MHz}\right.$, methanol- $\left.d_{4}, \delta(\mathrm{ppm})\right): 7.59-7.42(\mathrm{~m}, 5 \mathrm{H}$, aromatic protons of ring $\mathrm{B}), 7.35(\mathrm{~d}, 1 \mathrm{H}$,

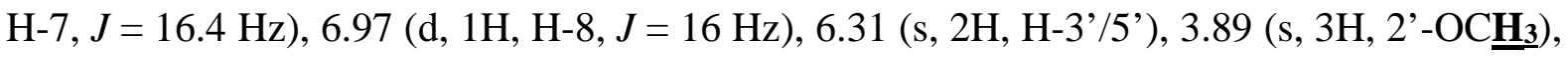

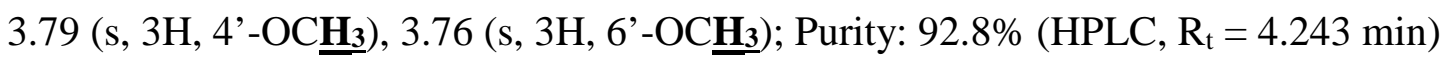

(E)-1-(4-(Allyloxy)-2-hydroxy-6-methoxyphenyl)-3-phenylprop-2-en-1-one (2)

Yield: $21.2 \mathrm{mg}$; Mp: 106-108 ${ }^{\circ} \mathrm{C}$; IR (KBr, cm $\left.{ }^{-1}\right)$ : 3448, 3190 (2'-OH), 2927 (C-H), 1628 $\left(\mathrm{C}=\mathrm{O}\right.$ ), 1573 (allylic $\mathrm{C}=\mathrm{C}$ ), 1422 (aromatic $\mathrm{C}=\mathrm{C}$ ), 1340, 1220 (phenolic $\mathrm{C}-\mathrm{O}$ ), $1114\left(\mathrm{O}_{-} \mathrm{CH}_{3}\right)$, 980, 790, 743; ${ }^{1} \mathrm{H}$ NMR (400 MHz, $\mathrm{CDCl}_{3}, \delta(\mathrm{ppm})$ ): 14.19 (s, 1H, 2'-OH), 7.54-7.34 (m, 5H, aromatic protons of ring B), $7.83(\mathrm{~d}, 1 \mathrm{H}, \mathrm{H}-7, J=15.6 \mathrm{~Hz}), 7.72(\mathrm{~d}, 1 \mathrm{H}, \mathrm{H}-8, J=15.6 \mathrm{~Hz})$, 6.04 (d, 1H, H-3', $J=2.4 \mathrm{~Hz}), 5.98$ (m, 1H, CH $\left.2-\underline{\mathbf{H}}=\mathrm{CH}_{2}\right), 5.94$ (d, 1H, H-5', $J=2.3 \mathrm{~Hz}$ ), $5.35\left(\mathrm{dd}, 1 \mathrm{H}, \mathrm{CH}_{2}-\mathrm{CH}=\mathrm{C} \underline{\mathbf{H}}-\mathrm{H}, J=1.4 \mathrm{~Hz}\right), 5.26\left(\mathrm{dd}, 1 \mathrm{H}, \mathrm{CH}_{2}-\mathrm{CH}=\mathrm{CH}-\underline{\mathbf{H}}, J=1.3 \mathrm{~Hz}\right), 4.50$ (d, $2 \mathrm{H}, \underline{\mathrm{CH}}_{2}-\mathrm{CH}=\mathrm{CH}_{2}, J=5.4 \mathrm{~Hz}$ ), 3.85 (s, 3H, 6'-OC每 3 ); Purity: 90\% (HPLC, $\mathrm{R}_{\mathrm{t}}=8.750$ $\min )$.

(E)-1-(2,4-Bis(benzyloxy)-6-methoxyphenyl)-3-phenylprop-2-en-1-one (3)

Yield: $10.6 \mathrm{mg}$; Mp: 57-60 ${ }^{\circ} \mathrm{C}$; IR (KBr, $\left.\mathrm{cm}^{-1}\right)$ : 3449, $2930(\mathrm{C}-\mathrm{H}), 1634(\mathrm{C}=\mathrm{O}), 1618$ and 1444 (aromatic $\mathrm{C}=\mathrm{C}$ ), 1385, 1227 (phenolic C-O), $1122\left(\mathrm{O}_{-} \mathrm{CH}_{3}\right), 974,812,770 ;{ }^{1} \mathrm{H}$ NMR (400 MHz, methanol- $\left.d_{4}, \delta(\mathrm{ppm})\right): 7.56-7.20(\mathrm{~m}, 15 \mathrm{H}$, aromatic protons), 6.98 (d, $1 \mathrm{H}, \mathrm{H}-7, J=$

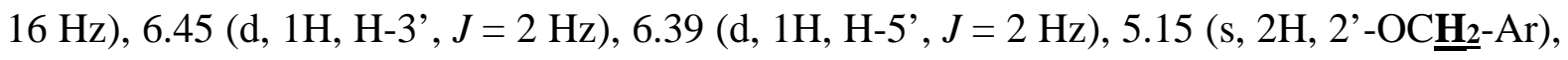

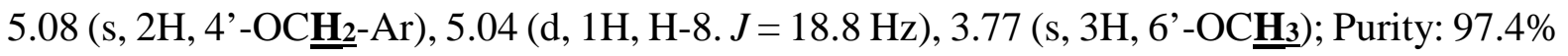
$\left(\mathrm{HPLC}, \mathrm{R}_{\mathrm{t}}=11.806 \mathrm{~min}\right.$ )

\section{4-Cinnamoyl-5-methoxy-1,3-phenylene diacetate (4)}

Cardamonin (40 mg, $0.15 \mathrm{mmol}$ ) was dissolved in dichloromethane by constant heating and stirring followed by the addition of acetic anhydride $(0.2 \mathrm{ml}, 2.12 \mathrm{mmol})$, pyridine $(0.2 \mathrm{ml}$, $2.47 \mathrm{mmol})$ and DMAP $(7.2 \mathrm{mg}, 0.059 \mathrm{mmol})$. The reaction mixture was left to stir for $24 \mathrm{~h}$ under reflux. The mixture was later washed with $4.5 \% \mathrm{HCl}$ and saturated aqueous sodium bicarbonate, followed by drying with $\mathrm{MgSO}_{4}$. The solvent was then evaporated and the resulting solid was purified using preparative TLC with a solvent system of chloroform:cyclohexane at 4:6.

Yield: $10.7 \mathrm{mg}$; Mp: 183-186 ${ }^{\circ} \mathrm{C}$; IR (KBr, cm $\left.{ }^{-1}\right)$ : 3449, $2919(\mathrm{C}-\mathrm{H}), 1642(\mathrm{C}=\mathrm{O}), 1419$ (aromatic $\mathrm{C}=\mathrm{C}$ ), 1385, 1213 (phenolic $\mathrm{C}-\mathrm{O}$ ), $1119\left(\mathrm{O}-\mathrm{CH}_{3}\right), 830,689,614 ;{ }^{1} \mathrm{H}$ NMR (400 MHz, acetone- $\left.d_{6}, \delta(\mathrm{ppm})\right): 7.68-7.42(\mathrm{~m}, 5 \mathrm{H}$, aromatic protons of ring $\mathrm{B}), 7.38(\mathrm{~d}, 1 \mathrm{H}$, H-7, $J=16.4 \mathrm{~Hz}$ ), 7.03 (d, 1H, H-8, $J=16.4 \mathrm{~Hz}$ ), 6.86 (d, 1H, H-3', $J=2 \mathrm{~Hz}), 6.66$ (d, 1H, H-

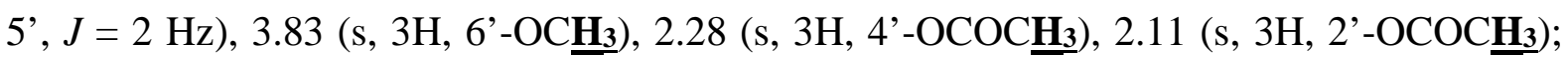
Purity: $98 \%$ (HPLC, $\mathrm{R}_{\mathrm{t}}=4.414 \mathrm{~min}$ ) 
Cardamonin (30 mg, $0.11 \mathrm{mmol}$ ) was dissolved in dichloromethane by constant heating and stirring followed by the addition of 4-fluorobenzoyl chloride $(1 \mathrm{ml}, 8.46 \mathrm{mmol})$, pyridine $(0.2$ $\mathrm{ml}, 2.47 \mathrm{mmol})$ and DMAP $(0.05 \mathrm{~g}, 0.41 \mathrm{mmol})$. The reaction mixture was left to stir for $24 \mathrm{~h}$ under reflux. The mixture was later washed with $4.5 \% \mathrm{HCl}$ and saturated aqueous sodium bicarbonate followed by drying with $\mathrm{MgSO}_{4}$. Finally, the solvent was evaporated and the product purified using preparative TLC with a solvent system of chloroform:cyclohexane at $4: 6$.

Yield: $18.4 \mathrm{mg}$; Mp: $168-171^{\circ} \mathrm{C}$; IR $\left(\mathrm{KBr}, \mathrm{cm}^{-1}\right)$ : $3083(\mathrm{C}-\mathrm{H}), 1683(\mathrm{C}=\mathrm{O}), 1623(\mathrm{C}=\mathrm{O}$ of cardamonin moiety), 1609 and 1428 (aromatic $\mathrm{C}=\mathrm{C}$ ), 1363, 1238 (phenolic C-O), 1131 (O$\left.\mathrm{CH}_{3}\right), 924,855,770 ;{ }^{1} \mathrm{H} \mathrm{NMR}\left(300 \mathrm{MHz}, \mathrm{CDCl}_{3}, \delta(\mathrm{ppm})\right): 8.14$ (dd, 2H, ortho-H of 4fluorobenzoyl moiety at position 2', $J=7.6,10.8 \mathrm{~Hz}), 8.05(\mathrm{dd}, 2 \mathrm{H}$, ortho-H of 4-fluorobenzoyl moiety at position 4', $J=7.2,12.4 \mathrm{~Hz}), 7.49-7.35(\mathrm{~m}, 5 \mathrm{H}$, aromatic protons of ring B), 7.44 (d, $1 \mathrm{H}, \mathrm{H}-7, J=22.4 \mathrm{~Hz}$ ), 7.34 (d, 1H, H-3', $J=2 \mathrm{~Hz}$ ), 7.15 (t, 2H, meta-H of 4-fluorobenzoyl moiety at position 2', $J=11.2 \mathrm{~Hz}), 7.06(\mathrm{t}, 2 \mathrm{H}$, meta-H of 4-fluorobenzoyl moiety at position 4', $J=11.2 \mathrm{~Hz}), 6.96$ (d, 1H, H-8, $J=21.2 \mathrm{~Hz}), 6.41$ (d, 1H, H-5', $J=2 \mathrm{~Hz}), 3.80$ (s, 3H, OC草3); Purity: 98\% (HPLC, $\left.\mathrm{R}_{\mathrm{t}}=2.176 \mathrm{~min}\right)$.

\section{4-Cinnamoyl-3-hydroxy-5-methoxyphenyl benzoate (6)}

Cardamonin (36 mg, $0.15 \mathrm{mmol}$ ) was dissolved in dichloromethane by constant heating and stirring followed by the addition of benzoyl bromide $(0.1 \mathrm{ml}, 0.78 \mathrm{mmol})$ and pyridine $(0.1 \mathrm{ml}$, $1.2 \mathrm{mmol})$. The reaction mixture was left to stir for $24 \mathrm{~h}$ under reflux. The solvent was evaporated and the crude product was purified using preparative TLC with a solvent system of ethylacetate:hexane at 7:3 followed by further purification using a solvent system of chloroform:cyclohexane at 1:1.

Yield: 9.4 mg; Mp: 105-106 ${ }^{\circ} \mathrm{C}$; IR $\left(\mathrm{KBr}, \mathrm{cm}^{-1}\right): 2930(\mathrm{C}-\mathrm{H}), 1733(\mathrm{C}=\mathrm{O}), 1636(\mathrm{C}=\mathrm{O}$ of cardamonin moiety), 1541 (aromatic $\mathrm{C}=\mathrm{C}$ ), 1340, 1243 (phenolic $\mathrm{C}-\mathrm{O}$ ), $1139\left(\mathrm{O}-\mathrm{CH}_{3}\right), 998$, 871, 705; ${ }^{1} \mathrm{H}$ NMR (300 MHz, $\mathrm{CDCl}_{3}, \delta(\mathrm{ppm})$ ): 13.57 (s, 1H, 2'-OH), 8.20-7.25 (m, 10H, aromatic protons ring B and benzoyl group), $7.63(\mathrm{~d}, 1 \mathrm{H}, \mathrm{H}-7, J=15.9 \mathrm{~Hz}), 7.57(\mathrm{~d}, 1 \mathrm{H}, \mathrm{H}-8$, $J=18 \mathrm{~Hz}$ ), 6.53 (d, 1H, H-3', $J=2.4 \mathrm{~Hz}$ ), 6.38 (d, 1H , H-5', $J=2.1 \mathrm{~Hz}$ ), 3.97 (s, 3H, 6'$\mathrm{OC}_{\mathbf{H}}$ ); Purity: $93.4 \%$ (HPLC, $\left.\mathrm{R}_{\mathrm{t}}=9.410 \mathrm{~min}\right)$.

\section{1-(2,4-Dihydroxy-6-methoxyphenyl)-3-phenylpropan-1-one (7)}

Cardamonin (30 mg, $0.11 \mathrm{mmol}$ ) was dissolved in methanol and $\mathrm{NiCl}_{2}$ (2 equivalent) was added to the mixture. The mixture was stirred and placed in an ice-bath. $\mathrm{NaBH}_{4}$ ( 6 equivalent) was later added and the mixture was left to stir for 5-10 min followed by dilution with $\mathrm{HCl}$ (37\%). Methanol was evaporated followed by the addition of water and the organic product was extracted by dichloromethane. Dichloromethane was finally evaporated and the crude product was purified via preparative TLC using a mobile phase of ethyl acetate:hexane in a ratio of $1: 1$. 
Yield: 2 mg; IR (KBr, cm$\left.{ }^{-1}\right)$ : 3437, $2919(\mathrm{C}-\mathrm{H}), 1628(\mathrm{C}=\mathrm{O}), 1455$ (aromatic $\left.\mathrm{C}=\mathrm{C}\right), 1382$, 1270, 1217 (phenolic C-O), $1114\left(\mathrm{O}_{-} \mathrm{CH}_{3}\right), 952,816,746 ;{ }^{1} \mathrm{H}$ NMR (300 MHz, $\mathrm{CDCl}_{3}$, $\delta(\mathrm{ppm})): 13.91\left(\mathrm{~s}, 1 \mathrm{H}, 2^{\prime}-\mathrm{OH}\right), 7.33-7.20(\mathrm{~m}, 5 \mathrm{H}$, aromatic protons of ring $\mathrm{B}), 5.99(\mathrm{~d}, 1 \mathrm{H}, \mathrm{H}-$

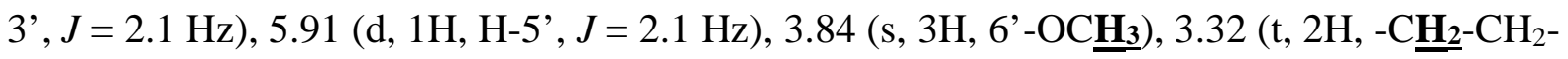
$\mathrm{Ar}, J=7.5 \mathrm{~Hz}), 2.99$ (t, 2H, $-\mathrm{CH}_{2}-\underline{\mathrm{CH}}_{2}-\mathrm{Ar}, J=7.5 \mathrm{~Hz}$ ); Purity: 96.8\% (HPLC, $\mathrm{R}_{\mathrm{t}}=5.167 \mathrm{~min}$ )

General method for synthesis of $(\mathbf{8})$ and $(\mathbf{9})$

The amine hydrochloride was initially fully dissolved in methanol followed by the addition of pyridine $(\sim 0.5 \mathrm{ml}, 6.18 \mathrm{mmol})$ and the mixture was left to stir under heating for $15 \mathrm{~min}$. Cardamonin (20-30 mg, $0.11 \mathrm{mmol}$ ) was later added followed by 2-3 drops of $\mathrm{HCl}$ and the reaction mixture was left to stir under reflux for $24 \mathrm{~h}$. Methanol was finally evaporated to obtain the product. In some cases further purification via preparative TLC was performed using a solvent system of chloroform:cyclohexane at 4:6.

The amines used were propylamine hydrochloride $(0.1 \mathrm{~g}, 1.05 \mathrm{mmol})$ and methoxyamine hydrochloride $(0.1 \mathrm{~g}, 1.20 \mathrm{mmol})$ for the synthesis of compounds $(\mathbf{8})$ and (9).

(Z)-5-Methoxy-4-(3-phenyl-1-(propylimino)propyl)benzene-1,3-diol (8)

Yield: $10 \mathrm{mg}$ (30\%); Mp: $145-150{ }^{\circ} \mathrm{C}$; IR (KBr, cm $\left.{ }^{-1}\right)$ : 3448, 3190 (2'-OH), 2967 (C-H), 1628 $(\mathrm{C}=\mathrm{N}), 1490$ (aromatic $\mathrm{C}=\mathrm{C}), 1383,1225$ (phenolic $\mathrm{C}-\mathrm{O}), 1114\left(\mathrm{O}_{-} \mathrm{CH}_{3}\right), 990,788,744 ;{ }^{1} \mathrm{H}$ NMR (400 MHz, $\mathrm{CDCl}_{3}, \delta(\mathrm{ppm})$ ): $14.28(\mathrm{~s}, 1 \mathrm{H}, \mathrm{OH}), 7.91$ (d, 1H, H-7, J = $\left.15.2 \mathrm{~Hz}\right), 7.79$ (d, $1 \mathrm{H}, \mathrm{H}-8, J=15.6 \mathrm{~Hz}), 7.64-7.29(\mathrm{~m}, 5 \mathrm{H}$, aromatic protons of ring B), $6.14(\mathrm{~d}, 1 \mathrm{H}, \mathrm{H}-3$ ',$J=$

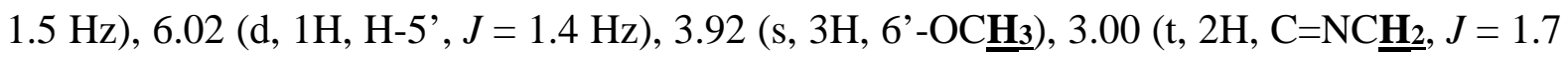
$\mathrm{Hz}$ ), 2.82 (m, $2 \mathrm{H}, \mathrm{NCH}_{2} \mathrm{CH}_{2}$ ), 1.70 (t, 3H, $\mathrm{NCH}_{2} \mathrm{CH}_{2} \mathrm{C}_{\mathbf{H}}, J=1.6 \mathrm{~Hz}$ ); Purity: 96.1\% (HPLC, $\left.\mathrm{R}_{\mathrm{t}}=3.888 \mathrm{~min}\right)$

\section{(Z)-1-(2,4-Dihydroxy-6-methoxyphenyl)-3-phenylpropan-1-one O-methyl oxime (9)}

Yield: $5.6 \mathrm{mg}$; Mp: 233-235 ${ }^{\circ} \mathrm{C}$; IR (KBr, cm$\left.{ }^{-1}\right)$ : 3451, 3277 (2'-OH), $2919(\mathrm{C}-\mathrm{H}), 1636(\mathrm{C}=\mathrm{N})$, 1457 (aromatic $\mathrm{C}=\mathrm{C}$ ), 1384, 1224 (phenolic C-O), $1116\left(\mathrm{O}_{-} \mathrm{CH}_{3}\right), 967,791,741 ;{ }^{1} \mathrm{H}$ NMR $\left(300 \mathrm{MHz}, \mathrm{CDCl}_{3}, \delta(\mathrm{ppm})\right): 14.17(\mathrm{~s}, 1 \mathrm{H}, \mathrm{OH}), 7.89$ (d, 1H, H-7, J = 15.5 Hz), $7.77(\mathrm{~d}, 1 \mathrm{H}, \mathrm{H}-$ $8, J=15.5 \mathrm{~Hz}), 7.62-7.39\left(\mathrm{~m}, 5 \mathrm{H}\right.$, aromatic protons of ring B), $6.12\left(\mathrm{~d}, 1 \mathrm{H}, \mathrm{H}-3^{\prime}, J=1.7 \mathrm{~Hz}\right)$,

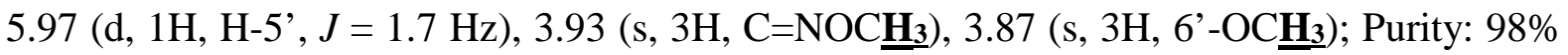
(HPLC, $\mathrm{R}_{\mathrm{t}}=2.115 \mathrm{~min}$ ).

Benzyl-2-(1-(2,4-dihydroxy-6-methoxyphenyl)-3-phenylpropylidene)hydrazine-1carbodithioate (10)

Cardamonin ( $8 \mathrm{mg}, 0.03 \mathrm{mmol})$ was dissolved in ethanol by constant heating and stirring followed by the addition of SBDTC $(0.018 \mathrm{~g}, 0.09 \mathrm{mmol}) .2-4$ drops of $\mathrm{HCl}$ were later added and the mixture was left to stir under reflux for $24 \mathrm{~h}$. The mixture was then cooled and the resulting solid precipitate was filtered, washed with ethanol and dried over silica gel.

Yield: $10.7 \mathrm{mg}$; Mp: $189-192{ }^{\circ} \mathrm{C}$; IR (KBr, cm $\left.{ }^{-1}\right)$ : 3415, 3213 (2'-OH), 3173 (NH), 2926 (C$\mathrm{H}), 1627(\mathrm{C}=\mathrm{N}), 1487$ (aromatic $\mathrm{C}=\mathrm{C})$, 1384, $1042(\mathrm{~N}-\mathrm{N}), 950(\mathrm{C}=\mathrm{S})$, 866, 826, 790, 744, 705; 
${ }^{1} \mathrm{H}$ NMR (400 MHz, $\mathrm{CDCl}_{3}, \delta(\mathrm{ppm})$ ): 14.16 (s, 1H, OH), 7.90 (d, 1H, H-7, J = $15.6 \mathrm{~Hz}$ ), 7.80 $(\mathrm{d}, 1 \mathrm{H}, \mathrm{H}-8, J=15.6 \mathrm{~Hz}), 7.64-7.31(\mathrm{~m}, 10 \mathrm{H}$, aromatic protons of ring $\mathrm{B}$ and ring of SBDTC moiety), 6.06 (d, 1H, H-3', $J=2.2$ Hz), 5.99 (d, 1H, H-5', $J=2.2 \mathrm{~Hz}$ ), 4.91 (s, 1H, NH), 4.52

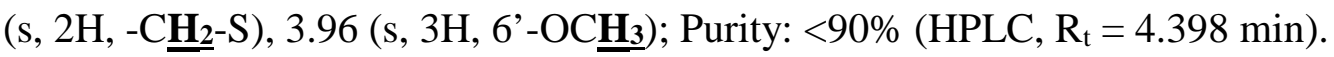

\section{5-Methoxy-4-(5-phenyl-4,5-dihydro-1H-pyrazol-3-yl)benzene-1,3-diol (11)}

Cardamonin (20 mg, $0.078 \mathrm{mmol}$ ) was dissolved in methanol and was left to stir under constant heating for $5 \mathrm{~min}$. To this solution was added excess $100 \%$ hydrazine hydrate $(0.3 \mathrm{ml}, 9.64$ $\mathrm{mmol}$ ) and the reaction mixture was left to stir under reflux for $24 \mathrm{~h}$. The solvent and hydrazine hydrate were evaporated, and the solid obtained was further purified by preparative TLC using a solvent system of chloroform:cyclohexane at $4: 6$, which resulted in a flaky brown solid product.

Yield: $22 \mathrm{mg}$ (98\%); Mp: 135-140 ${ }^{\circ} \mathrm{C}$; IR (KBr, cm $\left.{ }^{-1}\right)$ : 3423, $2919(\mathrm{C}-\mathrm{H}), 1618(\mathrm{C}=\mathrm{O}), 1463$ (aromatic $\mathrm{C}=\mathrm{C}$ ), 1384, 1213 (phenolic $\mathrm{C}-\mathrm{O}$ ), $1158\left(\mathrm{O}_{-} \mathrm{CH}_{3}\right), 956,816,765 ;{ }^{1} \mathrm{H}$ NMR $\left(400 \mathrm{MHz}, \mathrm{CDCl}_{3}, \delta(\mathrm{ppm})\right): 7.57-7.35(\mathrm{~m}, 5 \mathrm{H}$, aromatic protons of ring $\mathrm{B}), 7.13(\mathrm{~s}, 1 \mathrm{H}, \mathrm{NH})$, $6.52(\mathrm{dd}, 1 \mathrm{H}, \underline{\mathbf{H}}-\mathrm{C}-\mathrm{Ar}$ of pyrazoline ring, $J=2,8 \mathrm{~Hz}), 6.10(\mathrm{~d}, 1 \mathrm{H}, \mathrm{H}-3$ ',$J=2.3 \mathrm{~Hz}), 6.03$ (d, $1 \mathrm{H}, \mathrm{H}-5$ ', $J=2.4 \mathrm{~Hz}$ ), 3.94 (dd, 1H, Cㅡ-H of pyrazoline, $J=3.8,20.2 \mathrm{~Hz}$ ), 3.83 (dd, 1H, CH-

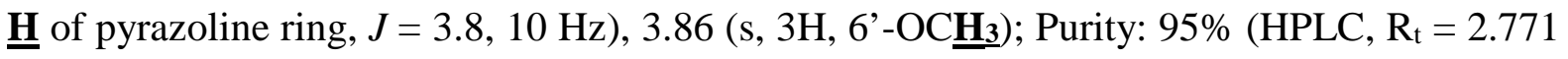
$\min )$

\section{5-Methoxy-4-(5-phenyl-4,5-dihydroisoxazol-3-yl)benzene-1,3-diol (12)}

To a mixture of cardamonin (30 mg, $0.11 \mathrm{mmol})$ and $\mathrm{NH}_{2} \mathrm{OH} \cdot \mathrm{HCl}(17 \mathrm{mg}, 0.24 \mathrm{mmol})$ in ethanol, $\mathrm{NaOH}$ (40 mg, $1 \mathrm{mmol}$ ) was added. The mixture was left to stir for $24 \mathrm{~h}$, and it was then left in a freezer overnight. Crushed ice and $2 \mathrm{ml}$ of $\mathrm{HCl}(37 \%)$ were later added to the mixture resulting in the formation of a pale yellow precipitate which was collected via vacuum filtration.

Yield: 16 mg; Mp: 220-221 º ; IR (KBr, cm $\left.{ }^{-1}\right)$ : 3448, 3220 (2'-OH), 2923 (C-H), 1610 (C=N), 1582 and 1482 (aromatic $\mathrm{C}=\mathrm{C}$ ), 1375, 1221 (phenolic $\mathrm{C}-\mathrm{O}), 1109\left(\mathrm{O}-\mathrm{CH}_{3}\right), 987,838,770 ;{ }^{1} \mathrm{H}$ NMR (400 MHz, acetone- $\left.d_{6}, \delta(\mathrm{ppm})\right): 7.55-7.35(\mathrm{~m}, 5 \mathrm{H}$, aromatic protons of ring $\mathrm{B}), 6.14(\mathrm{~d}$, $1 \mathrm{H}, \mathrm{H}-3$ ', $J=2 \mathrm{~Hz}$ ), 6.09 (d, 1H, H-5', $J=2 \mathrm{~Hz}$ ), 5.46 (dd, 1H, $\underline{\mathbf{H}}-\mathrm{C}-A r$ of isoxazoline ring, $J$

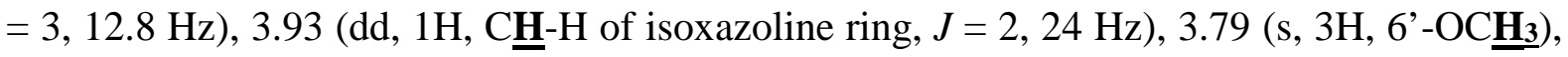
3.58 (dd, 1H, CH- $\underline{\mathbf{H}}$ of isoxazoline, $J=4,14 \mathrm{~Hz}$ ); Purity: 95\% (HPLC, $\mathrm{R}_{\mathrm{t}}=26.287 \mathrm{~min}$ )

\section{General method for synthesis of (13) and (14)}

Cardamonin (30 mg, $0.11 \mathrm{mmol})$ and, urea ( $40 \mathrm{mg}, 0.67 \mathrm{mmol}$ ) for synthesis of (13) or thiourea (40 mg, $0.53 \mathrm{mmol}$ ) for synthesis of (14), were added together in a round bottom flask. To this was added $\mathrm{NaOH}(0.2 \mathrm{~g}, 0.005$ moles $)$ dissolved in $80 \%$ ethanol, and the mixture was left to stir under reflux for more than $24 \mathrm{~h} .1 \mathrm{ml}$ of $\mathrm{HCl}(37 \%)$ was later added to neutralize the mixture and crushed ice was finally added resulting in the formation of a precipitate which was collected via vacuum filtration. 
Yield: $41 \mathrm{mg}$; Mp: 220-221 ${ }^{\circ} \mathrm{C}$; IR $\left(\mathrm{KBr}, \mathrm{cm}^{-1}\right)$ : 3437, $3226(\mathrm{NH}), 2965(\mathrm{C}-\mathrm{H}), 1661(\mathrm{C}=\mathrm{N})$, 1601 ( $\mathrm{NH}$ bend), 1591 and 1475 (aromatic $\mathrm{C}=\mathrm{C}$ ), 1384, 1221 (phenolic $\mathrm{C}-\mathrm{O}$ ), $1119\left(\mathrm{O}_{-} \mathrm{CH}_{3}\right)$, 969, 847, 766; ${ }^{1} \mathrm{H}$ NMR (400 MHz, acetone- $d_{6}, \delta(\mathrm{ppm})$ ): 7.54-7.34 (m, 5H, aromatic protons of ring B), $6.14\left(\mathrm{~d}, 1 \mathrm{H}, \mathrm{H}-3^{\prime}, J=2.4 \mathrm{~Hz}\right), 6.08(\mathrm{~d}, 1 \mathrm{H}, \mathrm{H}-5$ ', $J=2.4 \mathrm{~Hz}), 5.48(\mathrm{~d}, 1 \mathrm{H}, \mathrm{C} \underline{\mathbf{H}}$ of pyrimidine, $J=2.8 \mathrm{~Hz}$ ), $5.45(\mathrm{~d}, 1 \mathrm{H}, \mathbf{C} \underline{\mathbf{H}}$ of pyrimidine, $J=3.2 \mathrm{~Hz}), 3.98(\mathrm{~s}, 1 \mathrm{H}, \mathrm{NH}), 3.79$ (s,

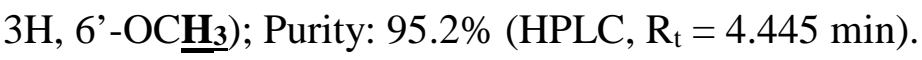

\section{4-(2-Mercapto-6-phenyl-1,6-dihydropyrimidin-4-yl)-5-methoxybenzene-1,3-diol (14)}

Yield: $35 \mathrm{mg}$; Mp: 213-216 ${ }^{\circ} \mathrm{C}$; IR $\left(\mathrm{KBr}, \mathrm{cm}^{-1}\right)$ : 3437, $3222(\mathrm{NH}), 2965(\mathrm{C}-\mathrm{H}), 1662(\mathrm{C}=\mathrm{N})$, 1601 ( $\mathrm{NH}$ bend), 1591 and 1475 (aromatic $\mathrm{C}=\mathrm{C}$ ), 1384, 1222 (phenolic $\mathrm{C}-\mathrm{O}$ ), $1119\left(\mathrm{O}_{-} \mathrm{CH}_{3}\right)$, 969, 847, 766; ${ }^{1} \mathrm{H}$ NMR (400 MHz, acetone- $d_{6}, \delta(\mathrm{ppm})$ ): 7.54-7.36 (m, 5H, aromatic protons

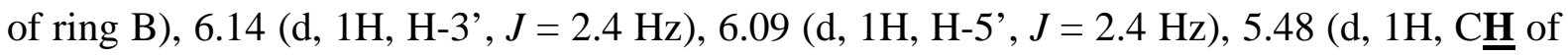
pyrimidine, $J=3.2 \mathrm{~Hz}$ ), $5.45(\mathrm{~d}, 1 \mathrm{H}, \mathbf{C} \underline{\mathbf{H}}$ of pyrimidine, $J=2.8 \mathrm{~Hz}), 3.97(\mathrm{~s}, 1 \mathrm{H}, \mathrm{NH}), 3.79$ (s,

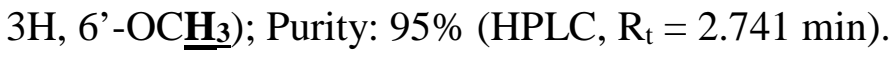

(E)-1-(4,6-Dihydroxy-3-iodo-2-methoxyphenyl)-3-phenylprop-2-en-1-one (15)

Cardamonin (50 mg, $0.19 \mathrm{mmol}$ ) and iodine $(42 \mathrm{mg}, 0.16 \mathrm{mmol})$ were added to a round bottom flask followed by the addition of $10 \mathrm{ml}$ of DMSO. The reaction mixture was left to stir under reflux for $6 \mathrm{~h}$. Water was then added to the mixture and the solid formed was filtered and washed with sodium thiosulfate in order to remove the excess iodine. The resulting solid was finally purified via preparative TLC using a mobile phase of cyclohexane:choroform in a ratio of $6: 4$.

Yield: $4.2 \mathrm{mg}$; Mp: 257-259 ${ }^{\circ} \mathrm{C}$; IR $\left(\mathrm{KBr}, \mathrm{cm}^{-1}\right)$ : 3450, $2920(\mathrm{C}-\mathrm{H}), 1639(\mathrm{C}=\mathrm{O}), 1625$ and 1483 (aromatic C=C), 1384, 1281, 1222 (phenolic C-O), $1115\left(\mathrm{O}_{-} \mathrm{CH}_{3}\right), 972,848,790 ;{ }^{1} \mathrm{H}$ NMR (300 MHz, DMSO, $\delta(\mathrm{ppm})): 15.16(\mathrm{~s}, 1 \mathrm{H}, \mathrm{OH}), 7.92$ (d, 1H, H-7, J = 15.6 Hz), 7.75 (d, $1 \mathrm{H}, \mathrm{H}-8, J=15.3 \mathrm{~Hz}), 7.76-7.45(\mathrm{~m}, 5 \mathrm{H}$, aromatic protons of $\operatorname{ring} \mathrm{B}), 6.26$ (s, 1H, H-3'), 3.92 (s, 3H, 6'-OC픈); Purity: 95\% (HPLC, $\left.\mathrm{R}_{\mathrm{t}}=7.781 \mathrm{~min}\right)$

(E)-1-(3-Bromo-4,6-dihydroxy-2-methoxyphenyl)-3-phenylprop-2-en-1-one (16)

Cardamonin (30 mg, $0.11 \mathrm{mmol}$ ) was dissolved in chloroform. This was followed by the addition of $1.2 \mathrm{ml}$ of bromine water and the reaction mixture was left to stir at room temperature for $24 \mathrm{~h}$. Chloroform was separated from the aqueous phase and later evaporated. The resulting solid was finally purified via preparative TLC using a mobile phase of cyclohexane:choroform in a ratio of $1: 1$.

Yield: $1.4 \mathrm{mg}$; Mp: 176-178 ${ }^{\circ} \mathrm{C}$; IR $\left(\mathrm{KBr}, \mathrm{cm}^{-1}\right)$ : 3464, 2921 (C-H), $1649(\mathrm{C}=\mathrm{O}), 1528$

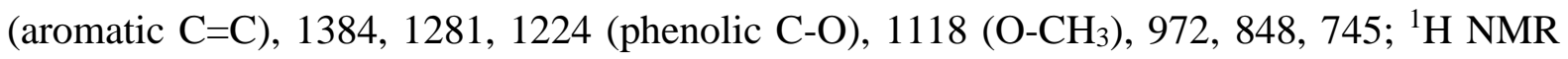
(300 MHz, DMSO, $\delta(\mathrm{ppm})$ ): 14.89 (s, 1H, 2'-OH), 7.90 (d, 1H, H-7, J = 15.6 Hz), 7.74 (d, 1H, $\mathrm{H}-8, J=15.6 \mathrm{~Hz}), 7.76-7.46(\mathrm{~m}, 5 \mathrm{H}$, aromatic protons of ring B), $6.26(\mathrm{~s}, 1 \mathrm{H}, \mathrm{H}-3$ '), 3.92 (s, 3H, 6'-OC프); Purity: 99\% (HPLC, $\mathrm{R}_{\mathrm{t}}=5.570 \mathrm{~min}$ ) 


\section{7-Hydroxy-5-methoxy-2-phenylchroman-4-one (17)}

Cardamonin (30 mg, $0.11 \mathrm{mmol}$ ) was dissolved in methanol followed by the addition of $10 \mathrm{ml}$ of $\mathrm{HCl}(37 \%)$. The reaction mixture was heated under reflux and left to stir for $72 \mathrm{~h}$. The solvent was later evaporated followed by the addition of purified water. The solid precipitate that formed was collected via filtration and further purified via preparative TLC using a mobile phase of cyclohexane:choroform in a ratio of 1:9.

Yield: $2.2 \mathrm{mg}$; Mp: 226-227 ${ }^{\circ} \mathrm{C}$; IR (KBr, cm$\left.{ }^{-1}\right): 3438,2919(\mathrm{C}-\mathrm{H}), 1657(\mathrm{C}=\mathrm{O}), 1620$ and 1441 (aromatic $\mathrm{C}=\mathrm{C}$ ), 1383, 1298, 1229 (phenolic C-O), $1116\left(\mathrm{O}-\mathrm{CH}_{3}\right), 773 ;{ }^{1} \mathrm{H}$ NMR (300 MHz, DMSO, $\delta(\mathrm{ppm})): 10.54\left(\mathrm{~s}, 1 \mathrm{H}, 4^{\prime}-\mathrm{OH}\right), 7.51-7.36(\mathrm{~m}, 5 \mathrm{H}$, aromatic protons of ring B), 6.07 (d, 1H, H-3', $J=2.1 \mathrm{~Hz}$ ), 6.00 (d, 1H, H-5', $J=2.1 \mathrm{~Hz}$ ), 5.48 (dd, 1H, O-Cㅍ-Ar, $J=$

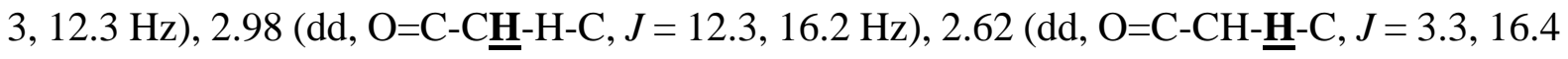

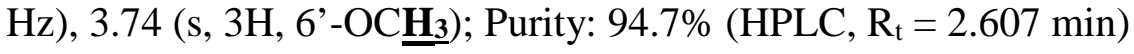

\section{3,6,7,8-Tetrahydroxy-5-methoxy-2-phenyl-4H-chromen-4-one (18)}

Cardamonin (30 mg, $0.19 \mathrm{mmol}$ ) was dissolved in methanol followed by the addition of $0.2 \mathrm{ml}$ $4 \% \mathrm{NaOH}$. The mixture was stirred at $0{ }^{\circ} \mathrm{C}$ for $30 \mathrm{~min} .0 .3 \mathrm{ml}$ of $30 \% \mathrm{H}_{2} \mathrm{O}_{2}$ was later added and the reaction mixture was left to stir for $24 \mathrm{~h}$ at room temperature. $10-12 \mathrm{ml}$ of $\mathrm{HCl}(37 \%)$ was then added and the reaction mixture was left to stand in the freezer for another $24 \mathrm{~h}$. The solid precipitate was finally collected and purified via preparative TLC using a mobile phase of ethyl acetate:hexane in a ratio of 6:4 followed by further purification using ethyl acetate:hexane in a ratio of $4: 6$

Yield: $18 \mathrm{mg}$; Mp: $143-145^{\circ} \mathrm{C}$; IR $\left(\mathrm{KBr}, \mathrm{cm}^{-1}\right)$ : 3450, $2925(\mathrm{C}-\mathrm{H}), 1638(\mathrm{C}=\mathrm{O}), 1541$ (aromatic $\mathrm{C}=\mathrm{C}$ ), 1373, 1238, 1219 (phenolic C-O), $1100\left(\mathrm{O}-\mathrm{CH}_{3}\right), 955,782 ;{ }^{1} \mathrm{H}$ NMR (300 MHz, DMSO, $\delta(\mathrm{ppm})):$ 7.76-7.44 (m, 5H, aromatic protons of ring B), 7.65 (s, 2H, 3'-OH \& 5'-OH), 3.73 (s,

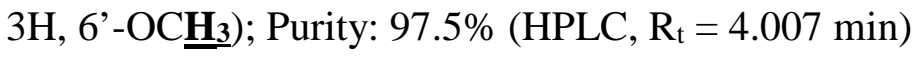

\section{$\left[\mathrm{Cu}\left(\mathrm{C}_{16} \mathrm{H}_{13} \mathrm{O}_{4}\right)_{2}\left(\mathrm{H}_{2} \mathrm{O}\right)_{2}\right] \cdot 2 \mathrm{H}_{2} \mathrm{O}(19)$}

Cardamonin (40 mg, $0.11 \mathrm{mmol}$ ) was dissolved in methanol by constant heating and stirring while copper (II) acetate $(30 \mathrm{mg}, 0.15 \mathrm{mmol}$ ) was separately dissolved in methanol in another beaker under the same conditions. $3 \mathrm{ml}$ of dilute $\mathrm{NaOH}$ was added to the cardamonin mixture followed by the addition of the copper (II) acetate solution. The reaction was left for $6-8 \mathrm{~h}$ with stirring under reflux. Finally, a brown precipitate formed and was collected via suction filtration.

Yield: $33.5 \mathrm{mg}$; Mp: >300 ${ }^{\circ} \mathrm{C}$; IR $\left(\mathrm{KBr}, \mathrm{cm}^{-1}\right)$ : 3448, $2926(\mathrm{C}-\mathrm{H}), 1598(\mathrm{C}=\mathrm{O}), 1460$ (aromatic $\mathrm{C}=\mathrm{C}$ ), 1384, 1230 and 1213 (phenolic C-O), $1117\left(\mathrm{O}_{-} \mathrm{CH}_{3}\right), 972,827,744 ;{ }^{1} \mathrm{H}$ NMR $(600 \mathrm{MHz}$, DMSO, $\delta(\mathrm{ppm})): 7.88(\mathrm{~d}, 1 \mathrm{H}, \mathrm{H}-7, J=10.8 \mathrm{~Hz}), 7.69-7.15(\mathrm{~m}, 5 \mathrm{H}$, aromatic protons of ring B), 7.57 (d, 1H, H-8, J = 12Hz), 7.45 (d, 1H, H-3', $J=6.6 \mathrm{~Hz}$ ), 7.42 (d, 1H, H-5', $J=6.0 \mathrm{~Hz}$ ),

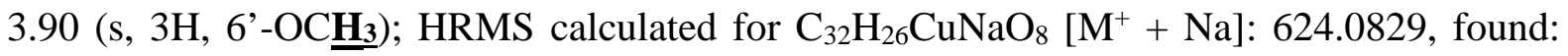
624.0783; Analytical calculated for $\left[\mathrm{Cu}\left(\mathrm{C}_{16} \mathrm{H}_{13} \mathrm{O}_{4}\right)_{2}\left(\mathrm{H}_{2} \mathrm{O}\right)_{2}\right] \cdot 2 \mathrm{H}_{2} \mathrm{O}: \% \mathrm{C}(57.01), \% \mathrm{H}(5.08)$, found: \%C (57.02), \%H (4.47); UV-Vis $\left(\lambda_{\max }, \mathrm{nm}\right)$ in DMSO: 291, 352, 432, 506, 600. 


\subsection{Cell culture}

Cardamonin and its analogues were tested against A549 (lung cancer cells) and HK1 cells (NPC cells). A549 cells were obtained from the American Type Culture Collection (ATCC) while HK1 cells were donated by Prof. GSW Tsao (Faculty of Medicine, The University of Hong Kong [22]. Cell cultures were generally maintained using RPMI 1640 (Gibco) supplemented with $10 \%$ fetal bovine serum (FBS) (Gibco), penicillin (100 U/ml, Gibco), streptomycin $\left(100 \mu \mathrm{g} / \mathrm{ml}\right.$, Gibco) and $2 \mathrm{mM}_{\mathrm{L}}$-Glutamine (Gibco) under humidified atmosphere containing $5 \% \mathrm{CO}_{2}$ in air at $37{ }^{\circ} \mathrm{C} .10 \% \mathrm{FBS}$ was replaced with $1 \% \mathrm{FBS}$ for treatment medium while adherent cells were dissociated using Trypsin-EDTA solution (Gibco).

\subsection{Cell viability assay}

The spectrophotometric MTS (3-(4,5-dimethylthiazol-2-yl)-5-(3-carboxymethoxyphenyl)-2(4-sulfophenyl)-2 $H$-tetrazolium) assay was used to assess cell viability. Aliquots of $100 \mu \mathrm{l}$ of 10,000 cells in an appropriate medium were dispensed into 96-well plates. Cells were incubated for $24 \mathrm{~h}$ at $37^{\circ} \mathrm{C}$ prior to treatment to allow cell attachment. $100 \mu \mathrm{l}$ of treatment medium were later added and the cells were incubated for $72 \mathrm{~h}$. $10 \mu \mathrm{l}$ of MTS reagent (Promega) was finally added to each well including the control and blank. The plate was wrapped in aluminium foil to protect from light and incubated at $37{ }^{\circ} \mathrm{C}$ for $1 \mathrm{~h}$ before reading the absorbance at $490 \mathrm{~nm}$ using a Tecan 200 ELISA plate reader.

\subsection{Migration assay}

Cells were seeded in 6-well plates and left to grow until confluency. This was followed by forming a scratch or "wound" in the layer of cells using a sterile $200 \mu 1$ pipette. The cells were washed with PBS and incubated with cardamonin $(25 \mu \mathrm{M})$ and compound $19(25 \mu \mathrm{M})$ in the presence of $10 \%$ FBS for $24 \mathrm{~h}$ and $48 \mathrm{~h}$. Magnified cells under the microscope were photographed at $0 \mathrm{~h}, 24 \mathrm{~h}$ and $48 \mathrm{~h}$. The images were analyzed via the software "ImageJ" in order to measure the area of the wound that has been occupied by the migrating cells. Results of the different treatment groups were then expressed as a percentage of the original area of the wound.

\subsection{Cell-cycle analysis}

Cell-cycle analysis of A549 and HK1 cells has been performed according to a previously reported method using a fluorochrome solution containing $50 \mathrm{mg} / \mathrm{mL}$ of propidium iodide (PI), $0.1 \mathrm{mg} / \mathrm{mL}$ of ribonuclease A, $0.1 \% v / v$ Triton $\mathrm{X}-100$ and $0.1 \% \mathrm{w} / v$ sodium citrate in $d-\mathrm{H}_{2} \mathrm{O}$ [23]. A549 and HK1 cells were each seeded in six-well plates at a density of $1 \times 10^{6}$ cells/well and treated for $24 \mathrm{~h}$ with 19 at its $\mathrm{IC}_{50}$ concentrations. There were also cells treated with DMSO (control). Cells were then harvested followed by washing with ice-cold PBS twice. Later, the pelleted cells were resuspended in $0.3-0.5 \mathrm{ml}$ of the fluorochrome solution and stored overnight in the dark at $4{ }^{\circ} \mathrm{C}$. Finally, the measurements were conducted using a Beckman Coulter Cytomics FC500 MCL flow cytometer and data analysis was performed via Weasel flow cytometry analysis software. 


\subsection{Flow cytometric detection of $\gamma-\mathrm{H} 2 \mathrm{AX}$}

Cells were seeded at a density of $1-1.5 \times 10^{6}$ in $10 \mathrm{~cm}^{2}$ dishes and allowed to adhere for $24 \mathrm{~h}$ at $37{ }^{\circ} \mathrm{C}$. The cells were treated with 19 for $24 \mathrm{~h}$ at its $\mathrm{IC}_{50}$ concentrations and then trypsinized, collected and fixed with $1 \%$ methanol-free formaldehyde in PBS. Following a 5 min incubation at room temperature, cells were permeabilised by adding $500 \mu 1$ of $0.4 \%$ Triton-X-100 in PBS and mixed gently. Cells were then rinsed with PBS, centrifuged and resuspended in $200 \mu 1$ of H2AX antibody (1:3333 dilution) at room temperature for $1.5 \mathrm{~h}$. Secondary antibody (goat anti-mouse Alexa Fluor 488; 1:1750 dilution) was later added and cells were incubated for $1 \mathrm{~h}$ at room temperature in the dark. Cells were washed with PBS and then resuspended in $300 \mu 1$ of $50 \mu \mathrm{g} / \mathrm{ml}$ propidium iodide/ $0.1 \mathrm{mg} / \mathrm{ml}$ RNAse A in PBS followed by incubation for at least $10 \mathrm{~min}$ at room temperature. Finally, the measurements were conducted using a Beckman Coulter Cytomics FC500 MCL flow cytometer and data analysis was performed via Weasel flow cytometry analysis software.

\subsection{Caspase-Glo 3/7 Apoptosis Assay}

A549 and HK1 cells were treated with $10 \mu \mathrm{M}$ of 19 for $12 \mathrm{~h}$ and caspase activation was investigated using a Caspase-Glo 3/7 assay (Promega) following the directions provided by the kit's manufacturer. Briefly, after the $12 \mathrm{~h}$ treatment, Caspase-Glo 3/7 reagent was added to the cells in a 1:1 ratio of reagent to cell culture medium in a 96-well plate, and mixed with a shaker followed by incubation at room temperature for a duration of $60 \mathrm{~min}$ for A549 cells and $30 \mathrm{~min}$ for HK1 cells. The resulting luminescence was read using a Varioscan flash multiplate reader.

\subsection{Caspase-Glo 8 \& Caspase-Glo 9 assays}

The protocol followed was similar to that of the Caspase-Glo 3/7 assay. However, CaspaseGlo 8 and Caspase-Glo 9 assays involved treating A549 and HK1 cells with $10 \mu \mathrm{M}$ of 19 for 6 $\mathrm{h}$ followed by adding the caspase reagent, shaking and incubating for $30 \mathrm{~min}$ for both A549 and HK1 cells. Each caspase assay was performed separately.

\subsection{Western blotting analysis}

Cells were seeded in dishes at a density of $\sim 1-2 \times 10^{6}$ per dish and were allowed to attach for $24 \mathrm{~h}$. The cells were later to $2 \times \mathrm{IC}_{50}$ of $\mathbf{1 9}$. Following exposure, cell lysates were prepared and protein concentrations evaluated by Bradford assay; $50 \mu \mathrm{g}$ protein was subjected to SDS-PAGE for separation. Whole PARP, cleaved PARP, Mcl-1, mTOR, p-mTOR, 4EBP1 and p-4EBP1 $1^{\circ}$ Abs were purchased from Cell Signaling Technologies. Anti-rabbit and anti-mouse immunoglobulin $\mathrm{G}(\mathrm{IgG})$ horseradish peroxidase-conjugated $2^{\circ}$ Abs were obtained from Dako.

\subsection{1 qPCR assay}

Total RNA was isolated from the cancer cells using TRIsure (Bioline), according to the manufacturer's instructions. This was followed by cDNA synthesis using Tetro cDNA Synthesis Kit (Bioline) according to the manufacturer's protocol. 
qPCR was performed on an ECO Illumina qPCR machine using a KAPA SYBR FAST qPCR Kit (Kapa Biosystems). Gene expression data were normalized to the endogenous control, GAPDH. The primer sequences were as follows: GAPDH: 5'GCACCGTCAAGGCTGAGAAC-3' (Forward), 5'- ATGGTGGTGAAGACGCCAGT-3' (Reverse); mTOR: 5'-CGCTGTCATCCCTTTATCG-3' (Forward), 5'ATGCTCAAACACCTCCACC-3' (Reverse).

The PCR cycling profile was as follows: One cycle at $50{ }^{\circ} \mathrm{C}$ for $2 \mathrm{~min}$ followed by another cycle at $95{ }^{\circ} \mathrm{C}$ for $3 \mathrm{~min}$. Then 40 cycles of $95{ }^{\circ} \mathrm{C}$ for $3 \mathrm{~s}, 63{ }^{\circ} \mathrm{C}$ for $30 \mathrm{~s}$ and $72{ }^{\circ} \mathrm{C}$ for $15 \mathrm{~s}$. Relative gene expression levels were calculated using the comparative $\mathrm{C}_{\mathrm{T}}$ method. 


\section{References}

[1] World Health Organization, http://www.who.int/mediacentre/factsheets/fs297/en/, Accessed Oct. 2016.

[2] Cancer Research UK, http://www.cancerresearchuk.org/aboutcancer/type/nasopharyngeal-cancer/, Accessed Oct. 2016.

[3] Zhang, J., Sikka, S., Siveen, K.S., Lee, J.H., Um, J-Y., Kumar, A.P., Chinnathambi, A., Alharbi, S.A., Basappa, Rangappa, K.S., Sethi, G., \& Ahn, K.S. (2017). Cardamonin represses proliferation, invasion, and causes apoptosis through the modulation of signal transducer and activator of transcription 3 pathway in prostate cancer. Apoptosis, 22, 158-168.

[4] Gonçalves, L. M., Valente, I. M., \& Rodrigues, J. A. (2014). An overview on cardamonin. Journal of Medicinal Food, 17(6), 633-640.

[5] Shrivastava, S., Jeengar, M. K., Thummuri, D., Koval, A., Katanaev, V. L., Marepally, S., \& Naidu, V. G. M. (2017). Cardamonin, a chalcone, inhibits human triple negative breast cancer cell invasiveness by downregulation of Wnt/ $\beta$-catenin signaling cascades and reversal of epithelial-mesenchymal transition. BioFactors, 43(2), 152-169.

[6] Pascoal, A., Ehrenfried, C., Lopez, B., de Araujo, T., Pascoal, V., Gilioli, R., Anhê, G., Ruiz, A., Carvalho, J., Stefanello, M., \& Salvador, M. (2014). Antiproliferative Activity and Induction of Apoptosis in PC-3 Cells by the Chalcone Cardamonin from Campomanesia adamantium (Myrtaceae) in a Bioactivity-Guided Study. Molecules, 19(2), 1843. Gabriel Anhê, Ana Ruiz, João Carvalho, Maria Stefanello,

[7] Break, M. K. b., Tahir, M. I. M., Crouse, K. A., \& Khoo, T.-J. (2013). Synthesis, Characterization, and Bioactivity of Schiff Bases and Their $\mathrm{Cd}^{2+}, \mathrm{Zn}^{2+}, \mathrm{Cu}^{2+}$, and $\mathrm{Ni}^{2+}$ Complexes Derived from Chloroacetophenone Isomers with $\mathrm{S}$ Benzyldithiocarbazate and the X-Ray Crystal Structure of S-Benzyl- $\beta$-N-(4chlorophenyl)methylenedithiocarbazate. Bioinorganic Chemistry and Applications, 2013, 13.

[8] Hemanth Kumar, K., \& Perumal, P. T. (2007). A novel one-pot oxidative cyclization of 2'amino and 2'-hydroxychalcones employing $\mathrm{FeCl}_{3} \cdot 6 \mathrm{H}_{2} \mathrm{O}$-methanol. Synthesis of 4-alkoxy-2aryl-quinolines and flavones. Tetrahedron, 63(38), 9531-9535.

[9] Zambare, A. S., Sangshetti, J., Kokare, N., \& Shinde, D. (2009). Development of mild and efficient method for synthesis of substituted flavones using oxalic acid catalyst. Chinese Chemical Letters, 2(2), 171-174.

[10] Ndoile, M. M., \& van Heerden, F. R. (2013). Total synthesis of ochnaflavone. Beilstein Journal of Organic Chemistry, 9, 1346-1351.

[11] Dinesha, Viveka, S., Priya, B. K., Pai, K. S. R., Naveen, S., Lokanath, N. K., \& Nagaraja, G. K. (2015). Synthesis and pharmacological evaluation of some new fluorine containing hydroxypyrazolines as potential anticancer and antioxidant agents. European Journal of Medicinal Chemistry, 104, 25-32. 
[12] Song, L. L., Kosmeder, J. W., Lee, S. K., Gerhäuser, C., Lantvit, D., Moon, R. C., Moriarty, R.M., \& Pezzuto, J. M. (1999). Cancer Chemopreventive Activity Mediated by 4'Bromoflavone, a Potent Inducer of Phase II Detoxification Enzymes. Cancer Research, 59(3), 578-585.

[13] Raman, N., Ravichandran, S., \& Thangaraja, C. (2004). Copper(II), cobalt(II), nickel(II) and zinc(II) complexes of Schiff base derived from benzil-2,4-dinitrophenylhydrazone with aniline. Journal of Chemical Sciences, 116(4), 215-219.

[14] Fares, M., Abou-Seri, S. M., Abdel-Aziz, H. A., Abbas, S. E. S., Youssef, M. M., \& Eladwy, R. A. (2014). Synthesis and antitumor activity of pyrido [2,3-d]pyrimidine and pyrido[2,3-d] $[1,2,4]$ triazolo[4,3-a]pyrimidine derivatives that induce apoptosis through G1 cell-cycle arrest. European Journal of Medicinal Chemistry, 83, 155-166.

[15] Qiu, J., Zhao, B., Shen, Y., Chen, W., Ma, Y., \& Shen, Y. (2013). A novel p-terphenyl derivative inducing cell-cycle arrest and apoptosis in MDA-MB-435 cells through topoisomerase inhibition. European Journal of Medicinal Chemistry, 68(Supplement C), 192202.

[16] Kuo, L. J., \& Yang, L.-X. (2008). $\gamma$-H2AX - A Novel Biomarker for DNA Double-strand Breaks. In Vivo, 22(3), 305-309.

[17] Nomura, M., Takahashi, T., Uesugi, A., Tanaka, R., \& Kobayashi, S. (2008). Inotodiol, a Lanostane Triterpenoid, from Inonotus obliquus Inhibits Cell Proliferation through Caspase-3dependent Apoptosis. Anticancer Research, 28(5A), 2691-2696.

[18] Ichim, G., \& Tait, S. W. G. (2016). A fate worse than death: apoptosis as an oncogenic process. Nature Reviews Cancer, 16(8), 539-548.

[19] Tang, Y., Fang, Q., Shi, D., Niu, P., Chen, Y., \& Deng, J. (2014). MTOR inhibition of cardamonin on antiproliferation of A549 cells is involved in a FKBP12 independent fashion. Life Sciences, 99(1-2), 44-51.

[20] Niu, P. G., Zhang, Y. X., Shi, D. H., Liu, Y., Chen, Y. Y., \& Deng, J. (2015). Cardamonin inhibits metastasis of Lewis lung carcinoma cells by decreasing mTOR activity. PLoS ONE, $10(5)$.

[21] Xue, Z. G., Niu, P. G., Shi, D. H., Liu, Y., Deng, J., \& Chen, Y. Y. (2015). Cardamonin Inhibits Angiogenesis by mTOR Downregulation in SKOV3 Cells. Planta Medica, 82(1-2), 70-75.

[22] Huang, D. P., Ho, J. H. C., Poon, Y. F., Chew, E. C., Saw, D., Lui, M., Li, C. L., Mak, L. S., Lai, S.H., \& Lau, W. H. (1980). Establishment of a cell line (NPC/HK1) from a differentiated squamous carcinoma of the nasopharynx. International Journal of Cancer, 26(2), 127-132. 
[23] Yap, V. A., Qazzaz, M. E., Raja, V. J., Bradshaw, T. D., Loh, H.-S., Sim, K.-S., Yong, K.T., Low, Y.-Y., \& Lim, K.-H. (2016). Fistulopsines A and B antiproliferative septicine-type alkaloids from Ficus fistulosa. Phytochemistry Letters, 15, 136-141. 